\title{
Seismic microzoning in Skopje, Macedonia
}

\author{
V.W. Lee ${ }^{\mathrm{a}}$, M.D. Trifunac ${ }^{\mathrm{a}, *}$, B.D. Bulajić ${ }^{\mathrm{b}}$, M.I. Manićc ${ }^{\mathrm{c}}$ D. Herak ${ }^{\mathrm{d}}$, M. Herak ${ }^{\mathrm{d}}$, G. Dimov \\ a Dept. of Civil Eng., Univ. of Southern California, Los Angeles, CA 90089, United States \\ b Dept. of Civil Eng. and Geodesy, Univ. of Novi Sad, 21000 Novi Sad, Republic of Serbia \\ c Crvena skopska, opština 4/1-1, Skopje, Macedonia \\ d Dept. of Geophysics, Faculty of Science, Univ. of Zagreb, 10000 Zagreb, Croatia \\ e Univ. Goce Delčev, 2000 Štip, Macedonia
}

\section{A R T I C L E I N F O}

\section{Keywords:}

Microzonation maps, which include

descriptions of site geology and site soil properties

Contribution of a large distant earthquake to the design strong motion amplitudes Computation of seismic hazard for earthquake sources, which follow different attenuation laws

\begin{abstract}
A B S T R A C T
Seismic microzonation maps for Skopje (Macedonia) are presented based on the Uniform-Hazard-Spectrum (UHS) methodology. UHS satisfies the guidelines for performance-based design (PBD), which require specification of two sets of spectral amplitudes, one for which the structure will remain essentially linear, and the other for which it will undergo a nonlinear response. The UHS method also considers the contributions from large distant earthquakes and includes simultaneous effects of site geology and site soils. The maps presented include the effects of near and distant large earthquakes in a balanced way, spatial distribution of seismic activity, site geology, and site soil properties.
\end{abstract}

\section{Introduction}

The design of structures to withstand earthquake shaking continues to be based on the expected amplitudes of strong earthquake ground motion, which are characterized in terms of maxima in the dynamic response, as given by the response-spectrum method [15,72,81]. Investigations and observations of damage caused by earthquakes, have shown that the observed variations are related to the geologic properties and soil site conditions. To account for such variations, microzoning maps can be formulated with coefficients that describe the variations in the amplitudes of shaking, and hence in the design forces $[26,50,58]$. The equivalent horizontal earthquake force, or the response-spectrum amplitudes for design, are then increased or decreased according to the values of the amplification coefficients defined in the microzoning maps.

The early development of seismic microzoning maps dates back to the Soviet Union (Akademia [1]) and Japan in the 1930s [26]. On the basis of many observations following earthquakes, guidelines were developed for the prediction of the relative increase or decrease of site intensities (and then of the associated peaks of strong motion amplitudes) based on the nature of site geology and surface soil $[14,50]$. Many published seismic microzonation maps from that time resembled the spatial distribution of geological and soil deposits in the area $[27,48,50,58]$. The local spatial variations were first based primarily on site geology $[50,58]$ and later expanded to include the effects of shallow sediments and local soils. Theoretical and observational studies in Japan [24,25] later evolved into methods that also included the properties of local site characteristics determined through field measurement of microtremors. After many years of research and the eventual introduction of probabilistic methods for evaluation of seismic design forces, we are now re-discovering that the old methods correctly recognized and emphasized the importance of both the site soil and site geology in influencing the spatial variations in seismic hazard. The results in this paper will show that site geology is indeed important for mapping seismic hazard and therefore must be included in the empirical scaling equations of strong ground motion.

Since the mid-1970s, after the first direct empirical scaling equations of spectral amplitudes started to appear, it became possible to formulate seismic zoning and microzoning in ways that considered the probabilities of earthquake occurrence, the spatial distributions of earthquake sources, the frequency-dependent attenuation of strongmotion amplitudes, and the site geologic and soil conditions [30-32,34,35,42-45,62-69,71,76]. The advantage of this approach has been that it simultaneously considers the contributions of all factors that influence the end result. Comparisons with earthquake occurrence in southern California have confirmed the merits of this approach. For example, seismic microzonation maps based on the uniform hazard method (UHM) [2,3] that were calculated and published in 1987 [36] for the Los Angeles metropolitan area have not been contradicted by any strong motion shaking from the earthquakes that have occurred in

\footnotetext{
* Corresponding author.

E-mail address: trifunac@usc.edu (M.D. Trifunac).
} 


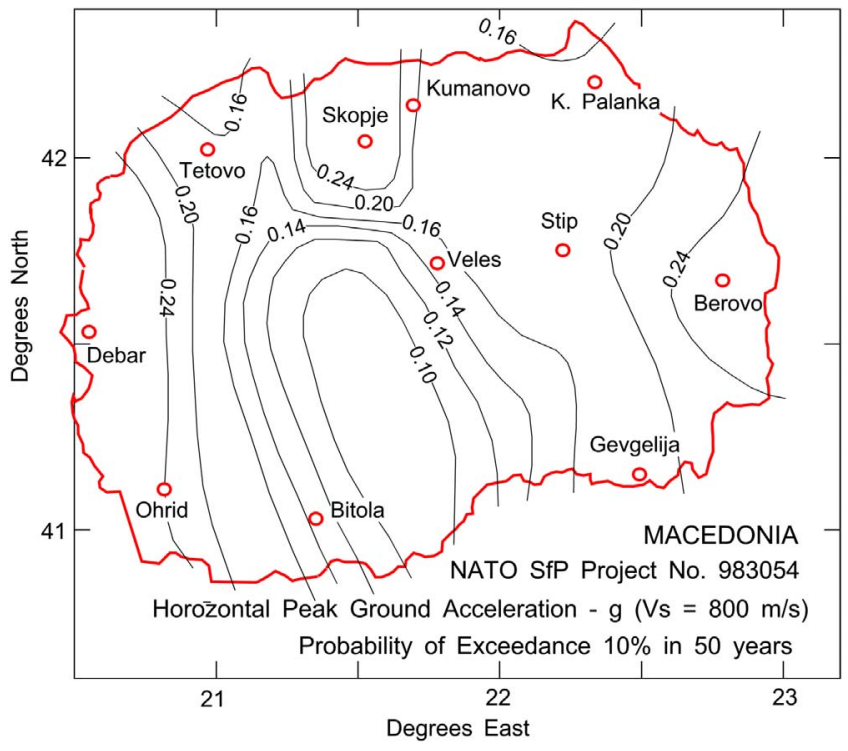

Fig. 1. A preliminary map of peak accelerations (g), at site A ( $800 \mathrm{~m} / \mathrm{s}$ ), for a probability of $10 \%$ exceedance, and an exposure period of $=50$ years (redrawn from [59]).

the area since $1985[70,74]$.

The purpose of this paper is to show how a model of seismic activity in the region, as well as the inclusion of geological site characterization (as in [77]), can be used to formulate microzoning maps of Skopje, Macedonia. The methodology, scaling equations, and descriptions of seismicity used in this paper are same as those described by $[46,47,40-42]$ and will not be repeated here. Useful features of this methodology are that (1) the detailed spatial variations of the geologic site conditions can be included directly in the calculation of spectral amplitudes, and as will be shown, are one of the significant factors influencing the final result; and (2) the consequences of contributions from large distant earthquakes (in this case from Vrancea in Romania) can also be included. The difference in the results of such an analysis from the old approach based on probabilistic mapping of only peak ground acceleration will become apparent in what follows.

Fig. 1 shows peak design accelerations for Skopje at $0.24 \mathrm{~g}$ (for the probability of $\mathrm{p}=0.1$ exceedance during an exposure period of $\mathrm{Y}=50$ years). Fig. 2 shows the corresponding seismic hazard map, also for the probability of $\mathrm{p}=0.1$ exceedance during an exposure period of $\mathrm{Y}=50$ years, but calculated by Lee and Trifunac [41]. It gives a $42 \%$ larger peak acceleration in Skopje, equal to $0.34 \mathrm{~g}$.

The procedures, which were used for development of the maps in Figs. 1 and 2, are very different and thus the results cannot be compared directly. Nevertheless, the end results suggest differences in peak accelerations in northern Macedonia approaching 50\% [40,41]. The amplitudes in Fig. 1 are based on scaling strong motion amplitudes by a weighted combination of five representative empirical-scaling equations for peak ground acceleration and for soil site condition A [59], while the amplitudes in Fig. 2 are for sites on geological basement rock $(s=2)$, and on "rock" soil sites $\left(S_{L}=0\right)$, and use attenuation equations for scaling Pseudo Relative Velocity Spectra (PSV) based on strong motion recordings in the former Yugoslavia $[37,38]$.

The approach implied for using the peak accelerations in Fig. 1 is that the acceleration at "rock" sites (represented in Fig. 1 by site class A) can be modified to other soil site classes by an analysis of a model that is capable of describing amplification of ground motion. This approach does not consider the geological characteristics of the site. In contrast, we include the effects of site geology via simplified site indicator variables in this paper. In several of our previous studies, we have argued that describing the site conditions in terms of only surface soil properties in the top $30 \mathrm{~m}\left(V_{30}\right.$ or $\mathrm{A}, \mathrm{B}, \mathrm{C}$, and $\mathrm{D}$, for example) does

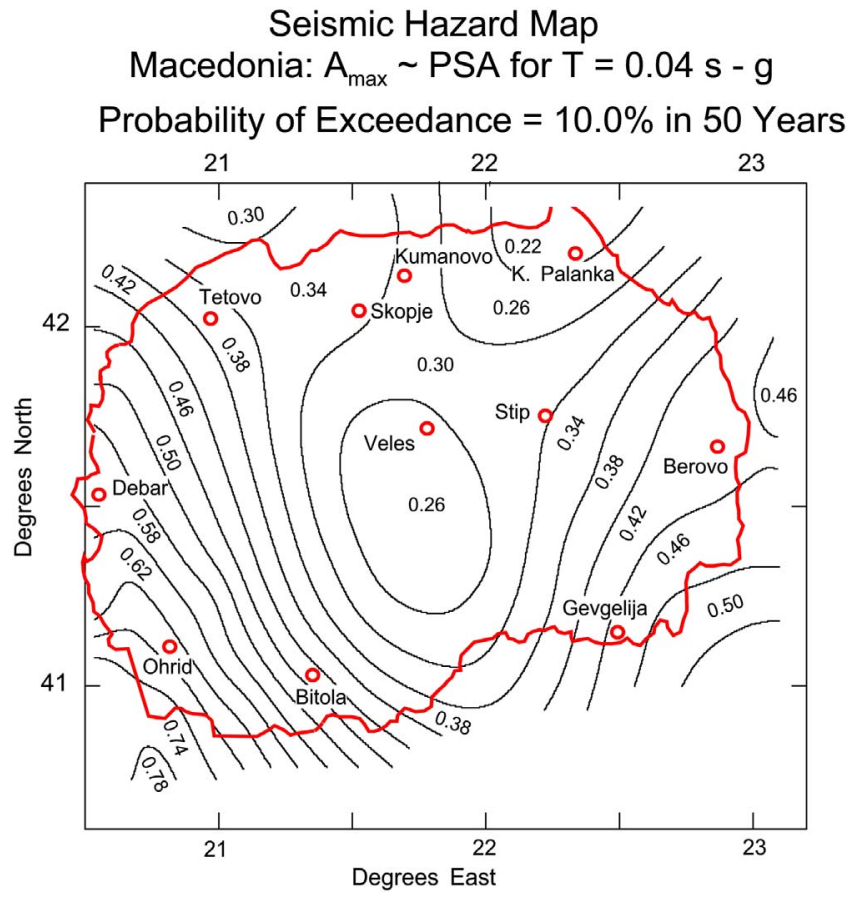

Fig. 2. The upper bound on peak accelerations in terms of $P S A(T)=(2 \pi / T) P S V(\mathrm{~g})$ computed from UHS at $T=0.04 \mathrm{~s}$ only for local seismicity within $175 \mathrm{~km}$ of the site [44]. The contributions from the Vrancea earthquake source in Romania are not included. Contours are shown for a probability of $10 \%$ exceedance and an exposure period of $Y$ $=50$ years (redrawn from [41]).

not lead to reliable results and should not be used [39]. In the following, we will work with the description of site parameters that describe site geology $(s=0,1$, or 2$)$ and site soil properties beyond the depth of $30 \mathrm{~m}\left(S_{L}=0\right.$ and 1$)$.

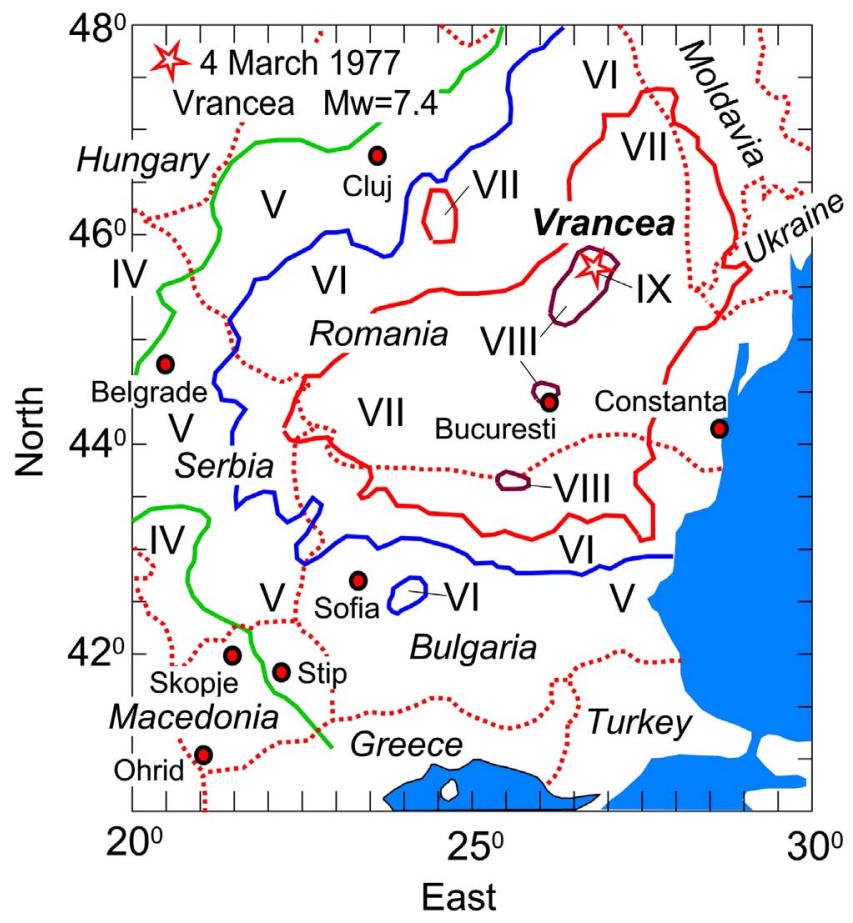

Fig. 3. A map of MKS intensity contours for the March 4, 1977 Vrancea earthquake (extracted from [28]) with $M_{w}=7.4, H=98 \mathrm{~km}$, and $I_{0}=$ IX. The Vrancea source zone is centered near $45.88^{\circ} \mathrm{N}$ and $26.98^{\circ} \mathrm{E}$ in Romania, where intermediate and large earthquakes occur at depths between 60 and $200 \mathrm{~km}$. During this earthquake, the MKS intensity was IV at an epicentral distance of $620 \mathrm{~km}$ in Skopje. 
PSA(with Vrancea) / PSA(without Vrancea)

Uniform Hazard Spectra at $T=0.04$ to $2.00 \mathrm{~s}, \mathrm{~s}=2, \mathrm{~S}_{\mathrm{L}}=0$
Probability of Exceedance $=10.0 \%$ in 50 Years
Macedonia

$40^{\circ} 35^{\prime}-42^{\circ} 24^{\prime} \mathrm{N}$ $20^{\circ} 32^{\prime}-23^{\circ} 12^{\prime} \mathrm{E}$

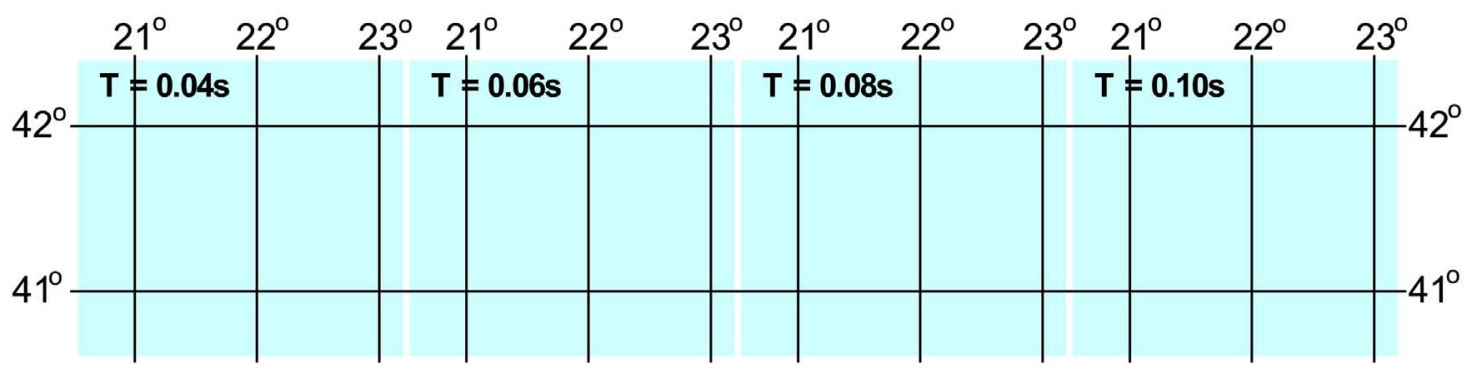

PSV Ratios:
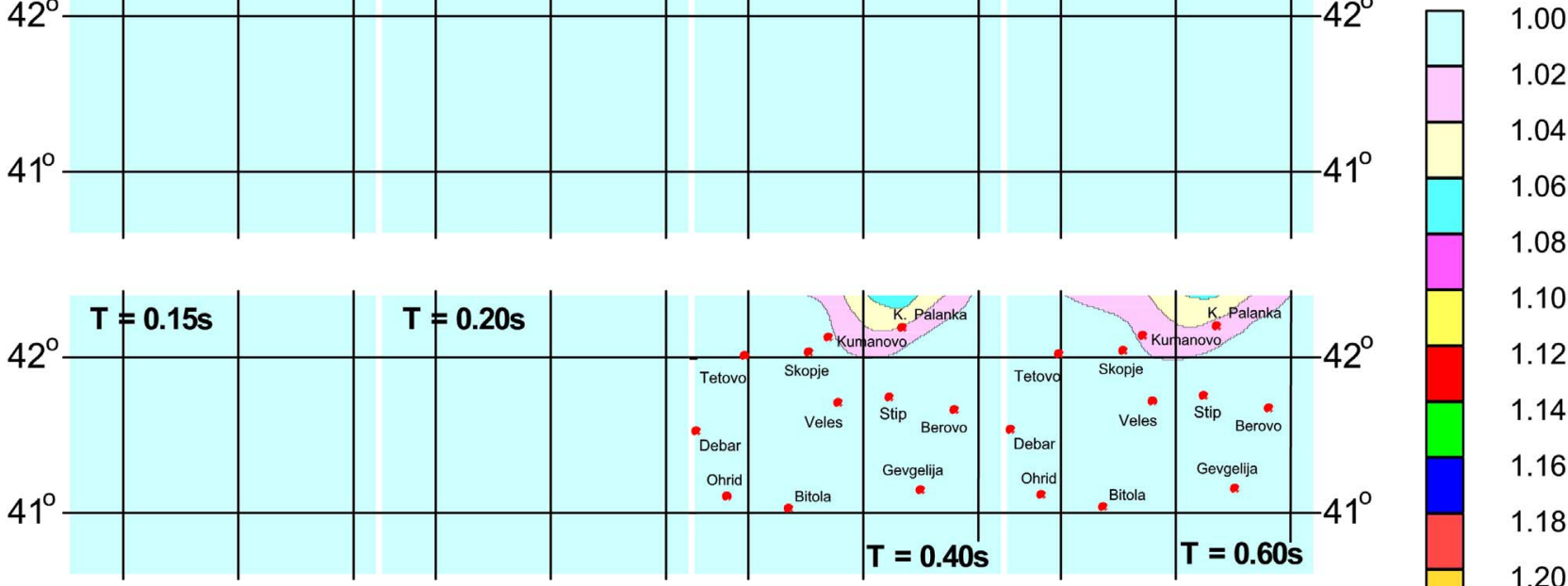

1.10

1.12

1.14

1.16

1.18

1.22

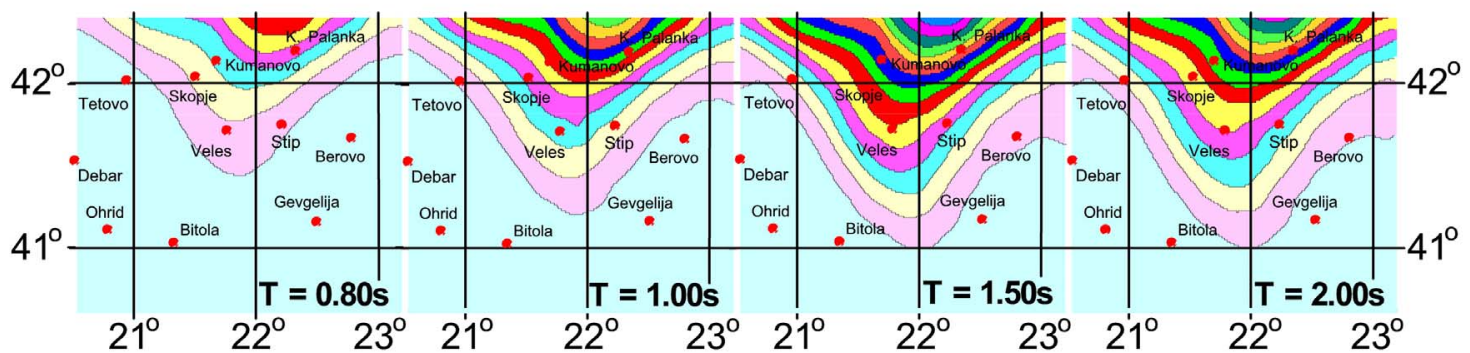

1.24

1.26

1.28

1.30

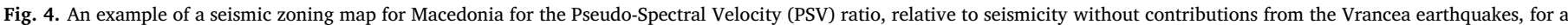

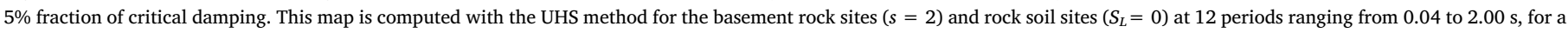
probability of exceedance of $\mathrm{p}=0.10$, and for an exposure time of $\mathrm{Y}=50$ years (redrawn from [41]).

The computation of hazard maps begins with a definition of spatial distribution of seismic sources and their activity in time. The description of this activity, as used in this paper, is briefly outlined in Appendix A. The next step involves the selection of attenuation equations that describe how the desired quantity representing strong ground motion attenuates with distance. The last step combines the contributions of all earthquake sources surrounding the site to compute the distribution functions of the quantity being evaluated at the site and plotting maps to show its spatial distribution.

The performance-based design guidelines in Eurocode 8 [10] (EC8) are expressed by no-collapse and damage limitation requirements. The no-collapse requirement is associated with a large and hence nonlinear response and the soil-structure system period $T_{\text {nonlinear }}$, while the damage limitation requirement is associated with an essentially linear response and hence a shorter equivalent system period, $T_{\text {linear }}$. Because $T_{\text {nonlinear }}$ and $T_{\text {linear }}$ are associated with different probabilities of exceedance, their respective spectral amplitudes cannot be specified with the same fixed shape spectrum and two corresponding peak accelerations. This is because the spectral shape is different for the different exceedance probabilities [75].

Beyond this, in our previous work we have described other concerns that point against using the maps like the one shown in Fig. 1. One such concern is that the hazard contributions from large Vrancea earthquakes (Fig. 3) cannot be included when the scaling of design motions is performed via peak accelerations. The reader will find further discussion regarding these concerns in $[40,41]$. We have shown, for example, that the Vrancea earthquakes dominate seismic hazard in eastern Serbia for intermediate and long periods of strong ground motion. This domination diminishes with increasing epicentral distance, and in northern Macedonia it is down to a range of several to several tens of percents (Fig. 4). In eastern and southwestern Macedonia, this contribution becomes even smaller due to active seismicity in nearby Bulgaria and Albania [41].

Fig. 4 shows the ratio of spectral velocities computed with contributions relative to contributions without the Vrancea earthquakes. It is seen that in the high-frequency range (higher than about $2 \mathrm{~Hz}$ ), the contribution to spectral velocities from the Vrancea earthquakes can be neglected for all sites in Macedonia for $\mathrm{p}=0.1$ and $\mathrm{Y}$ $=50$ years. However, as oscillator periods become longer, these contributions increase. At a frequency of $0.7 \mathrm{~Hz}$, the Vrancea earthquakes increase spectral velocities by about $13 \%$ in Skopje. Fig. 4 also shows that south and southwest of the line connecting Tetovo with 


\section{Urban Plan of Skopje}

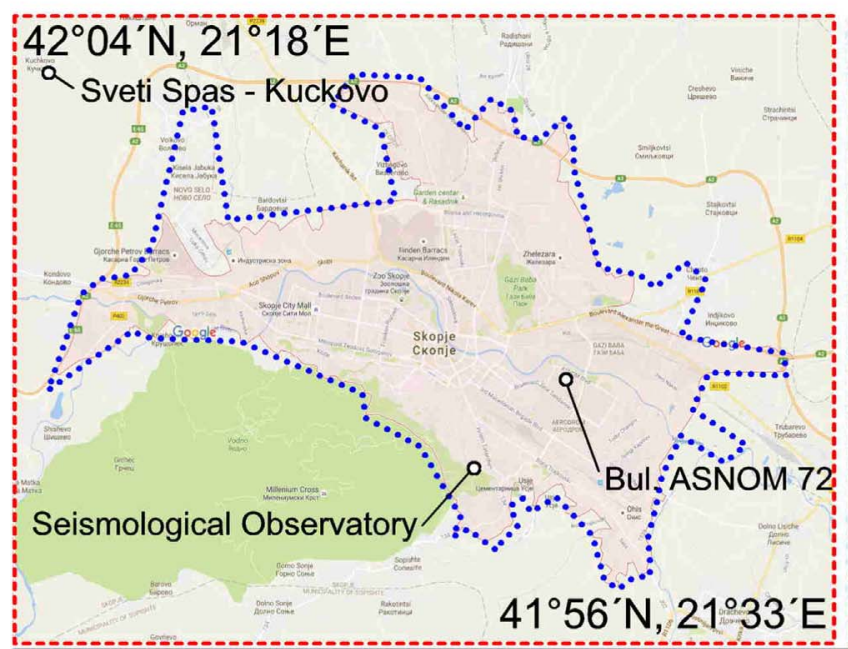

Geological Site Parameters

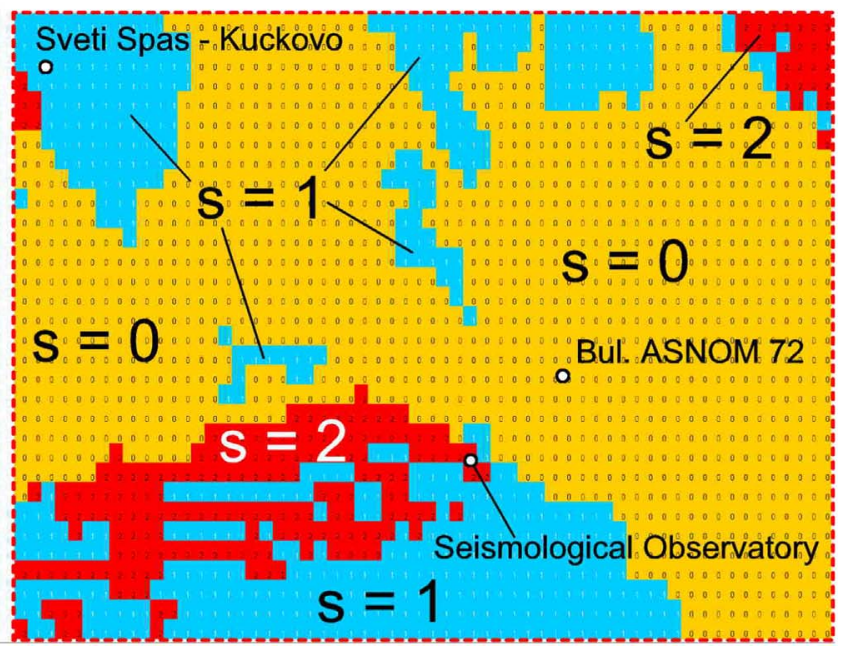

Fig. 5. The General Urban Plan of the City of Skopje (left) and the Geological Site Parameters ( $=0,1$ or 2) in the same area (right).

Bitola, Gevgelija, and Berovo, at epicentral distances greater than about $600 \mathrm{~km}$, the contribution to seismic hazard from the Vrancea earthquakes can be neglected in Macedonia (Tetovo - $645 \mathrm{~km}$; Bitola $706 \mathrm{~km}$; Gevgelija - $638 \mathrm{~km}$; Berovo - $578 \mathrm{~km}$ ). In the areas where local seismic activity is high, the distance of this line to Vrancea decreases, and where the local seismicity is low, this distance increases.

\section{Skopje and its surroundings: geological site classification}

Geological site classification for computations of Uniform Hazard Spectra for the area surrounding the city of Skopje is based on our interpretation of the geological maps of the Skopje region. There are four basic geological maps that cover the area defined by the "General Urban Plan of the City of Skopje 2012-2022" [9] that include: "Basic geological map - Kačanik" [4]; "Basic geological map - Kumanovo" [5]; "Basic geological map - Skopje" [6]; and "Basic geological map - Titov Veles" [7].

The area that covers the "General Urban Plan of the City of Skopje 2012-2022" (Fig. 5) was divided into cells of $15 \times 15 \mathrm{~s}$ in geographic coordinates between $41^{\circ} 56^{\prime} \mathrm{N}$ and $42^{\circ} 04^{\prime} \mathrm{N}$; that is, between $21^{\circ} 18^{\prime} \mathrm{E}$ and $21^{\circ} 33^{\prime} \mathrm{E}$. For each of the 1920 analyzed cells, the site geology was described by the predominant lithostratigraphic formations and depths.

To determine the geological site condition $s$ for the city of Skopje, we interpreted the description of the site geology that was compiled for each cell. We used the classification methodology proposed by Trifunac and Brady [77] and then classified the site geology for each cell as either "basement rock" $(s=2)$, "alluvial and sedimentary deposits" $(s=0)$, or "intermediate sites" $(s=1)$. The result is shown in the right half of Fig. 5.

\section{Mapping seismic hazard via uniform hazard spectra}

Mapping the amplitudes of $P S A(T)=2 \pi P S V(T) / T$ where $P S A(T)$ is the Pseudo Absolute Acceleration Spectrum, $P S V(T)$ is the Pseudo Relative Velocity Spectrum, and $T$ is the oscillator period, for $T=0.04 \mathrm{~s}$ gives an upper bound for peak ground acceleration, because in the limit as $T$ tends to zero, $P S A(T)$ tends to peak ground acceleration.
Fig. 6a through d show this upper bound for peak ground acceleration for a $10 \%$ exceedance probability, exposure periods of $Y=10$ and 50 years, and for "rock" $\left(S_{L}=0\right)$ and stiff $\left(S_{L}=1\right)$ soil site conditions. The geological site parameters $s$ are included in the hazard calculations. The spatial variations seen in these figures are dominated by the distance to seismic activity northwest and southeast of Skopje and by the geological site-condition parameters $s=0,1$ and 2 (see Fig. 5, right). For a $10 \%$ exceedance probability and an exposure time of $\mathrm{Y}$ $=50$ years, the average peak acceleration in Fig. $6 \mathrm{~b}$ is consistent with our overall regional estimate [41] of $0.34 \mathrm{~g}$ (shown in Fig. 2). For sites on $S_{L}=1$ (stiff soil), (Fig. 6d) peak accelerations are about 1.7 times larger.

We note that the amplitudes of peak accelerations shown in Fig. 6a through $\mathrm{d}$ are not sensitive to the occurrence of distant earthquakes in the Vrancea source zone in Romania. These figures further show that peak accelerations are larger on basement rock $(s=2)$ than on intermediate rock sites $(s=1)$ by about $30-35 \%$ for both "rock" soil sites $\left(S_{L}=0\right)$, and for stiff soil sites $\left(S_{L}=1\right)$.

In Fig. 6a through d, we emphasize the degree to which peak accelerations (here $P S A(T)$ at $T=0.04 \mathrm{~s}$ approximately represents peak ground acceleration) are dependent on the geological site conditions, and provide a rough basis for comparison with previously published results (e.g., as in Fig. 1). Our results in Fig. 6a through d are not intended for and should not be used in scaling the design spectral amplitudes. Correct scaling of design spectra can be accomplished via microzonation maps based on UHS amplitudes. This will be described in the following section.

\section{Contribution of the Vrancea earthquakes to seismic hazard}

The Vrancea earthquakes occur at a large epicentral distance from Skopje (620 km; Fig. 3). This results in attenuation of high-frequency spectral amplitudes [46,47], thus the UHS for peak accelerations in Skopje (Fig. 4), for a typical range of exceedance probabilities, are dominated only by local seismicity. Consequently, for typical hazard mapping of peak accelerations in Skopje, the Vrancea earthquakes can be ignored. However, this is different in cases of intermediate and longperiod spectral amplitudes, in which the Vrancea earthquakes (with 
a

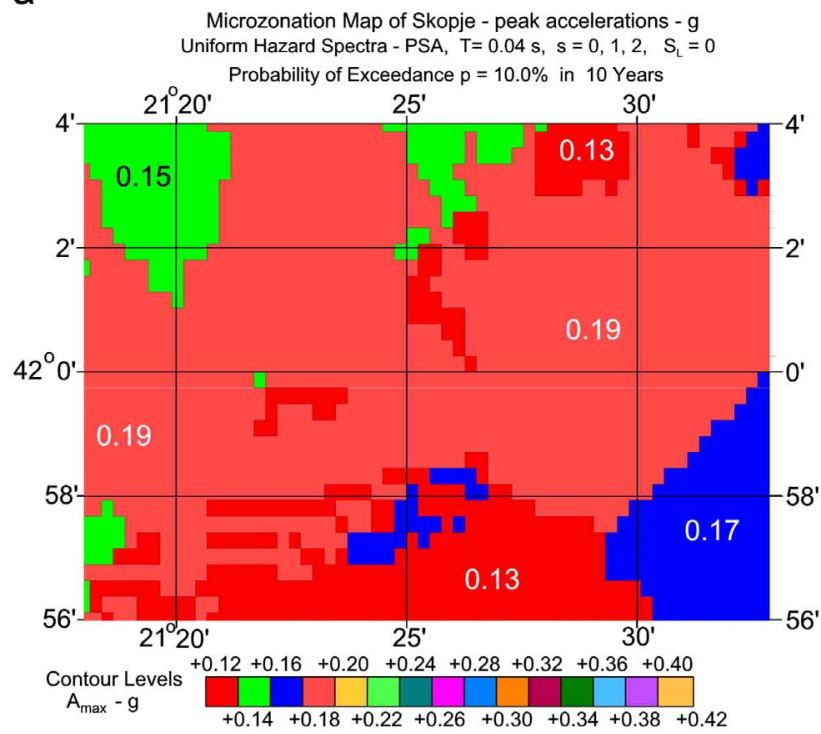

C

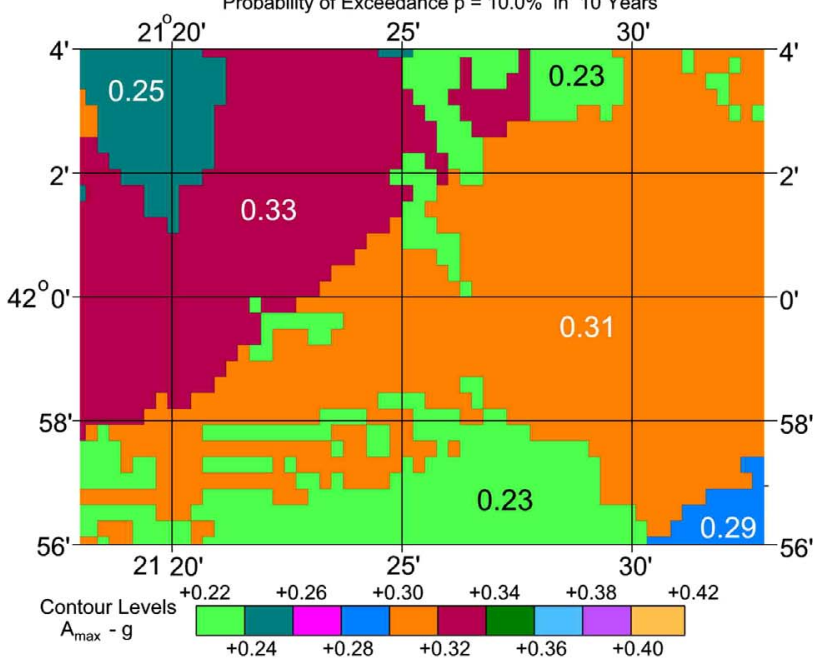

b

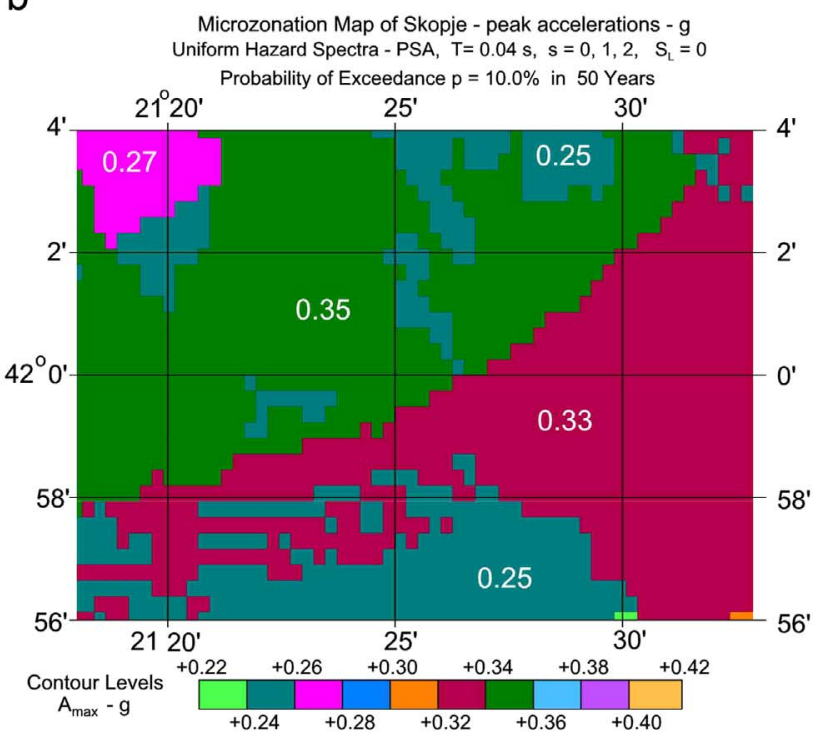

d

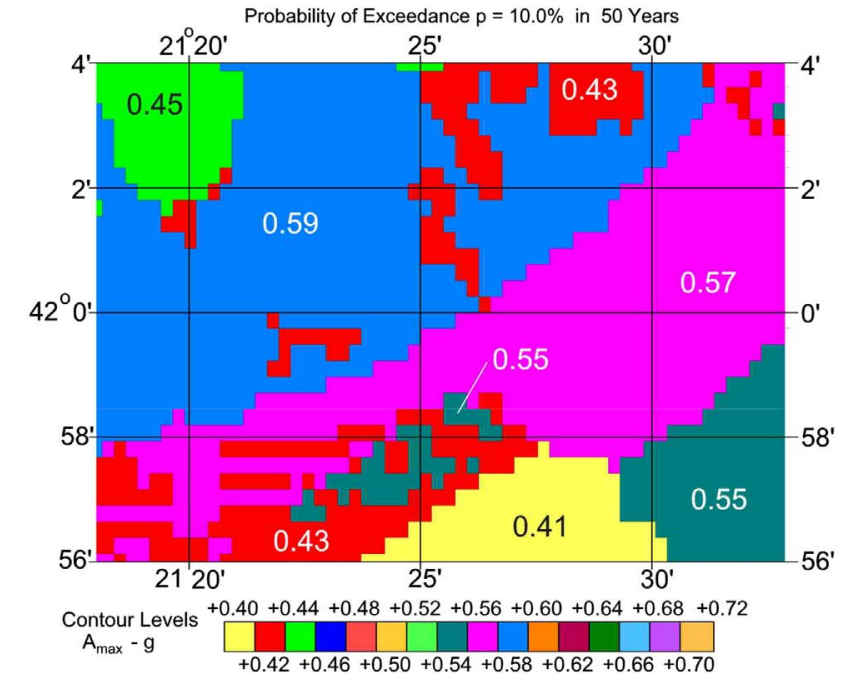

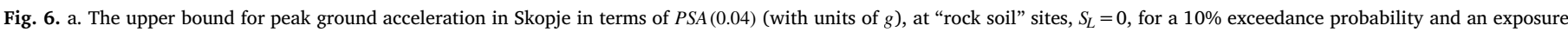

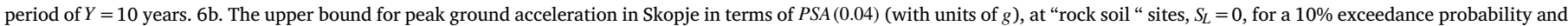

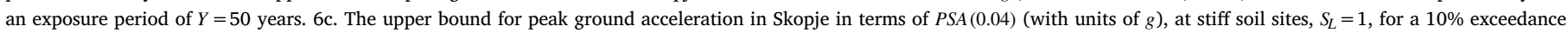

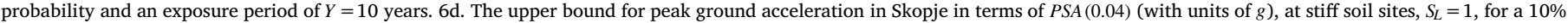
exceedance probability and an exposure period of $Y=50$ years.

$M>6.5$ ) contribute progressively more as periods of ground motion become longer.

Fig. 7a through d show contours of $P S A(T=1.0 \mathrm{~s})$ with contributions from the Vrancea earthquakes. The Vrancea earthquakes contribute appreciably at $T=1.0 \mathrm{~s}$ and longer periods, and this contribution progressively increases in Macedonia as one moves northeast [41]. The contribution of the Vrancea sources is also larger where the local seismicity is relatively low (see Appendix A and Fig. 4).

A detailed comparison of Fig. 7a through d, with Fig. 6a through d, shows that the spatial distribution of short- and long-period amplitudes is different. This is caused by a variable shape of UHS and by the contribution to long-period spectral amplitudes from the Vrancea sources with strong motion waves arriving from the northeast. Fig. 8a and $\mathrm{b}$ also show this in terms of the ratios of spectral amplitudes computed relative to the spectral amplitudes without the contribution from the Vrancea sources.

The relative increase of spectral amplitudes due to the contribution from the Vrancea earthquakes, shown in Fig. 8a and b, is the same for all comparisons among the same geological site conditions $(s=0,1$ and 2 ) and for the oscillator period shown $(T=1.00 \mathrm{~s})$. However, the amplitudes of $P S A(T)=(2 \pi / T) P S V$ for UHS at $T=1.00 \mathrm{~s}$ at sites on intermediate rocks $(s=1)$ will be larger than at the basement rock sites $(s=2)$. In this paper, we show most results for the sites on geological basement rock $(s=2)$ to facilitate qualitative comparisons with previously published results, which are typically shown only for the type A sites. 
a Microzonation Map of Skopje - with contribution from Vrancea earthquakes Uniform Hazard Spectra - PSA - $\mathrm{g}, \mathrm{T}=1.0 \mathrm{~s}, \mathrm{~s}=0,1,2, \mathrm{~S}_{\mathrm{L}}=0$

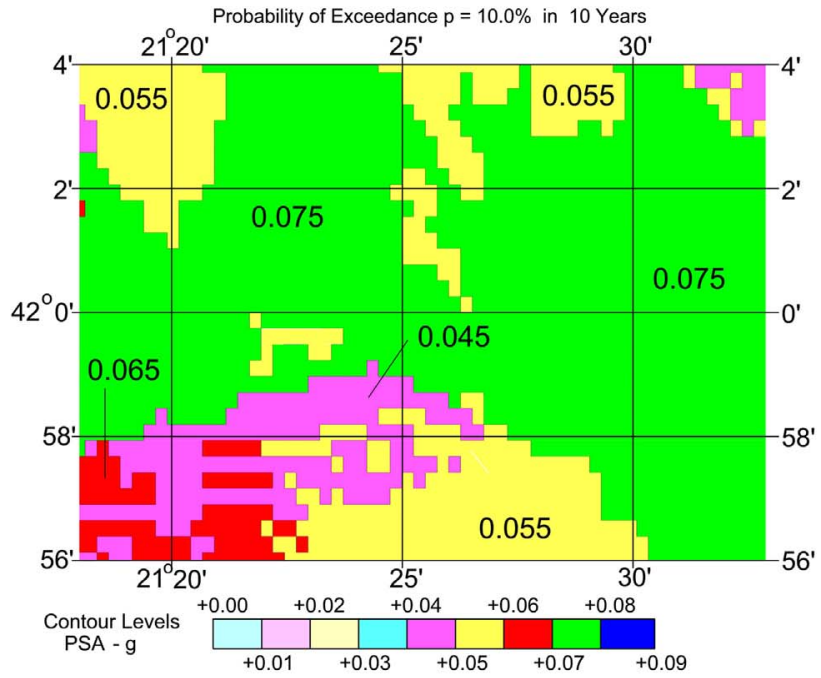

C

Microzonation Map of Skopje - with contribution from Vrancea earthquakes Uniform Hazard Spectra - PSA - $\mathrm{g}, \mathrm{T}=1.0 \mathrm{~s}, \mathrm{~s}=0,1,2, \mathrm{~S}_{\mathrm{L}}=1$

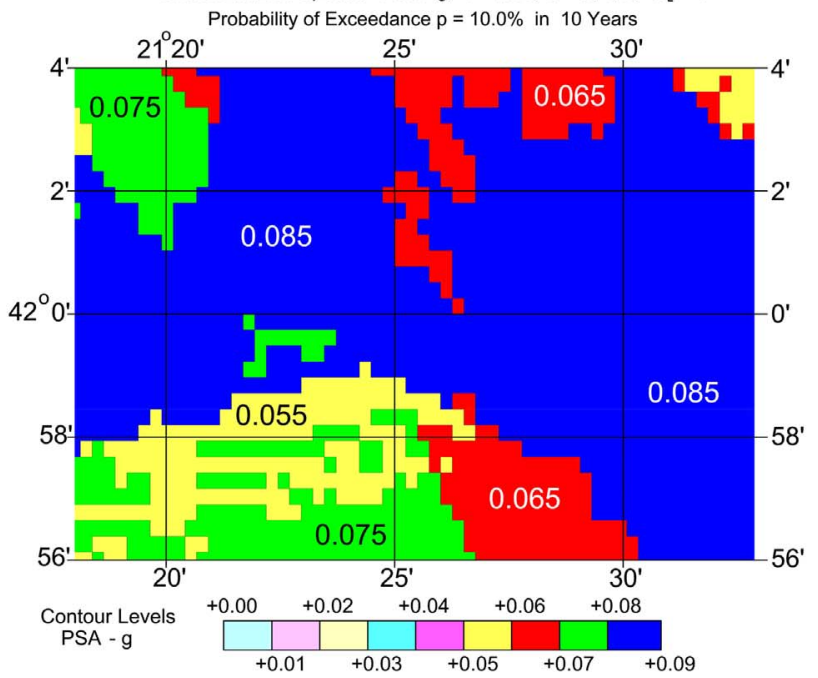

b Microzonation Map of Skopje - with contribution from Vrancea earthquakes Uniform Hazard Spectra - PSA - $g, T=1.0 \mathrm{~s}, \mathrm{~s}=0,1,2, \mathrm{~S}_{\mathrm{L}}=0$ Probability of Exceedance $p=10.0 \%$ in 50 Years

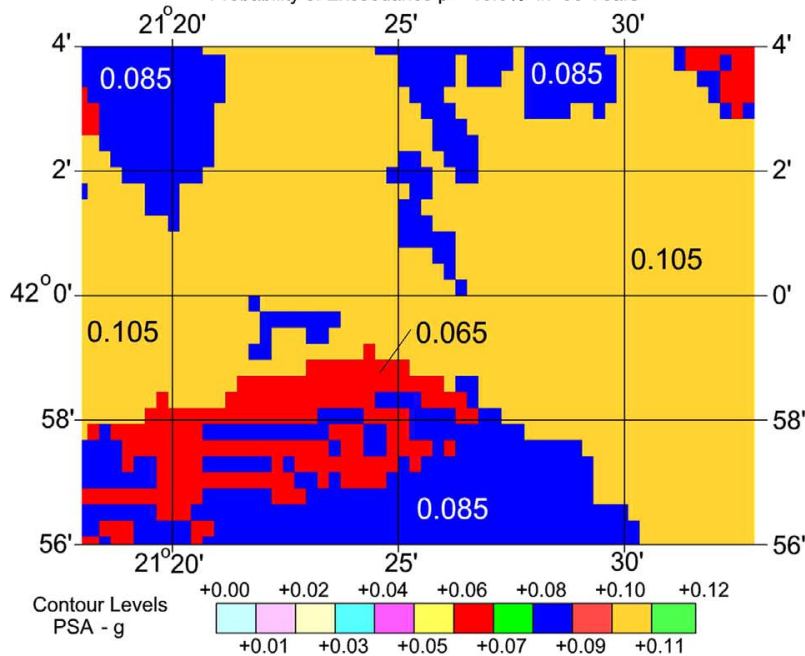

d

Microzonation Map of Skopje - with contribution from Vrancea earthquakes Uniform Hazard Spectra - PSA - g, T=1.0 s, s = 0, 1, 2, $S_{L}=1$ Probability of Exceedance $p=10.0 \%$ in 50 Years

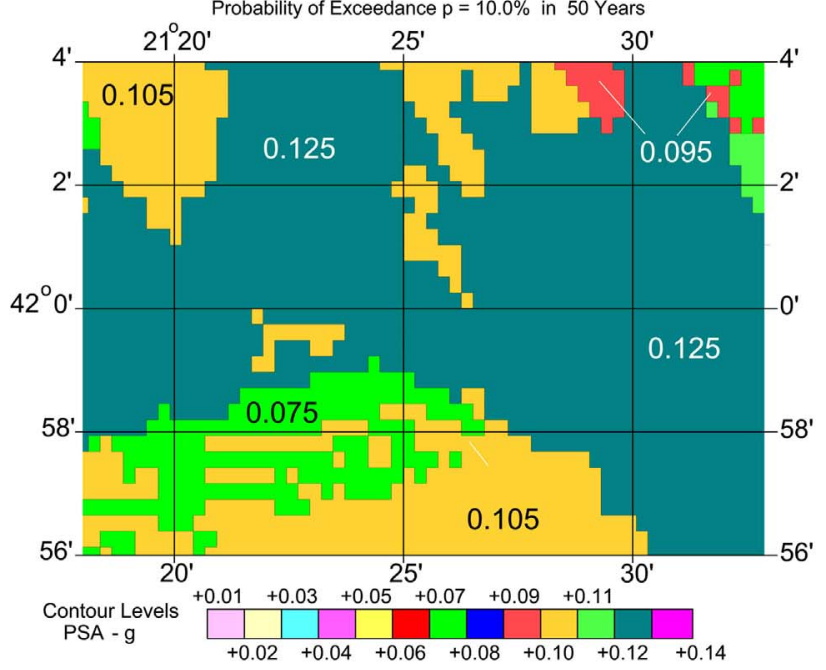

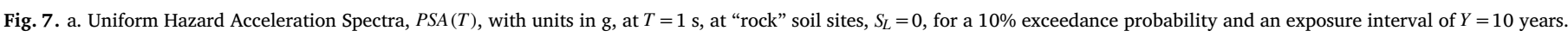

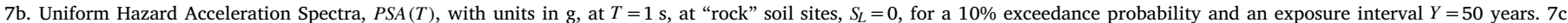

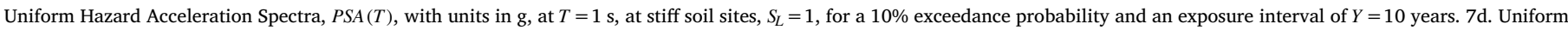
Hazard Acceleration Spectra, $P S A(T)$, with units in g, at $T=1 \mathrm{~s}$, at stiff soil sites, $S_{L}=1$, for a $10 \%$ exceedance probability and an exposure interval of $Y=50$ years.

\section{Practical determination of UHS}

Design spectra based on UHS at a building site can be calculated for each site-specific condition, but these calculations are time-consuming and require detailed knowledge to select the required scaling parameters. A simple, convenient alternative for engineering applications, which Lee and Trifunac introduced in the mid-1980s, is to prepare maps of UHS for given response periods, site conditions, probabilities of exceedance and exposure time, and then to read the spectral amplitudes from the map contours. The report, "Microzonation of a Metropolitan Area," describes this procedure and presents examples of how it can be carried out [36]. Fig. 9a through d show examples of such maps for $\log _{10} P S V(T)$ amplitudes at 12 periods ranging from $0.04 \mathrm{~s}$ to $2.00 \mathrm{~s}$, for $5 \%$ damping, horizontal motions, at "rock" and stiff soil sites $S_{L}=0$ and 1), for $10 \%$ exceedance probability and exposure periods of $Y=10$ and
50 years. By reading the spectral amplitudes at the given location, the UHS of PSV can be constructed by interpolating the values read from the 12 periods. Examples of such interpolations are illustrated in Figs. 10a through $12 \mathrm{~b}$, at three sites with different geological and soil site parameters (Skopje -Seismological Observatory, with $s=2$ and $S_{L}=0$; Kuckovo, with $s=1$ and $S_{L}=1$; and Bul. ASNOM 72 with $s=0$ and $S_{L}=1$ ).

Figs. 10a through $12 \mathrm{~b}$ all show a monotonically increasing contribution from the Vrancea sources as the oscillator periods become longer. Overall, long-period spectral amplitudes tend to be larger on $s$ $=0$ and $S_{L}=1$ (Bul. ASNOM 72, Fig. 12a,b) than on $s=2$ and $S_{L}=0$ (Skopje-Seismological Observatory, Fig. 10a,b), provided the sites are at comparable distance from large Vrancea sources, as those are in these examples. 
a

Microzonation Map of Skopje - PSA(with Vrancea)/PSA(without Vrancea) Uniform Hazard Spectra - PSA - g, at T=1.00 s, $\mathrm{s}=0,1,2, \mathrm{~S}_{\mathrm{L}}=0$ Probability of Exceedance $p=10.0 \%$ in 10 Years

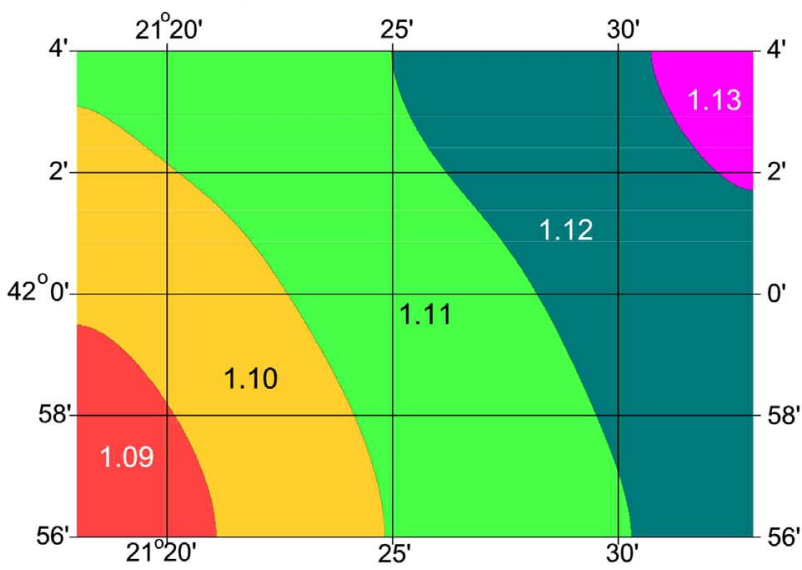

b

Microzonation Map of Skopje - PSA(with Vrancea)/PSA(without Vrancea) Uniform Hazard Spectra - PSA - g, at T=1.00 s, $s=0,1,2, \quad S_{L}=0$ Probability of Exceedance $p=10.0 \%$ in 50 Years

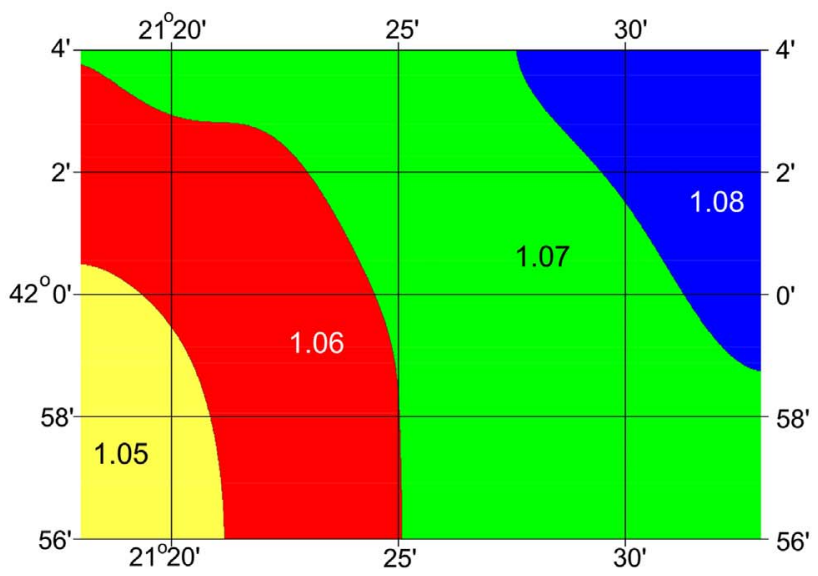

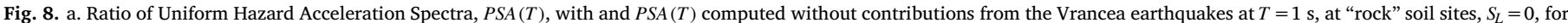

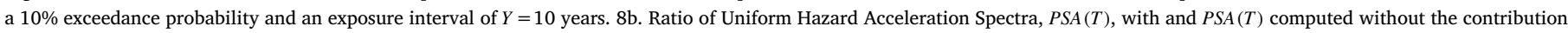
from the Vrancea earthquakes at $T=1 \mathrm{~s}$, at "rock" soil sites, $S_{L}=0$, for a $10 \%$ exceedance probability and an exposure interval of $Y=50$ years.

\section{Discussion and conclusions}

We have shown that the regional variations of UHS amplitudes over an area of a large city are considerable. In the examples shown for Skopje, three main sources of these variations are (1) the geological and soil site conditions; (2) the local seismicity mainly northwest and southeast of Skopje; and (3) the contributions from large Vrancea earthquakes at a distance of about $620 \mathrm{~km}$ northeast in Romania. The different effects of distance from these sources can clearly be seen in Fig. 6a through d (along the northwest to southeast direction), 7a through $7 \mathrm{~d}$, and $8 \mathrm{a}$ and $8 \mathrm{~b}$ (along the southwest to northeast direction), and 9a through 9d (at short and long periods, respectively). Relative contributions from these sources will differ for different cites depending on the degree to which geologic and soil site conditions vary, as well as on the relative strength and direction towards local versus distant earthquakes.

In Macedonia, peak accelerations are dominated by the local seismic activity almost everywhere, and the contribution from the Vrancea earthquakes can be neglected. However, in central and northeastern parts of the country, the intermediate- and long- period spectral amplitudes are affected by contributions from large Vrancea earthquakes. These contributions are small in the southwestern, southern and southeastern areas of Macedonia, and strongest in the northcentral and northeastern areas (Fig. 4; [41]).

In all calculations throughout this paper we have used empirical scaling equations that were developed from the strong motion data recorded in the former Yugoslavia $[37,38,47]$. This data had only a few recordings at deep soil sites $\left(S_{L}=2,[71,73]\right)$ and hence our empirical scaling equations for PSV amplitudes do not include the scaling in terms of $S_{L}=2$. Therefore, examples including $S_{L}=2$ are not included in this paper. For future engineering design at $S_{L}=2$ sites, additional analyses will be required to modify UHS presented in this paper to approximate the amplitudes expected at $S_{L}=2$ sites. This can be based on several other scaling equations that do include $S_{L}=2$ scaling factors in California and elsewhere [33].

It is noted that all results presented in this paper are only of preliminary nature. Our scaling models for strong ground motion in former Yugoslavia are more than 20 years old and based on strong motion data, which was recorded up to the early 1980 s $[23,78,79]$. Our model for scaling of PSV spectra in Serbia [47]—that we are also using in the case of Macedonia in this paper for earthquakes in the Vrancea source zone-was published recently. However, that paper only includes large Vrancea earthquake data and has not been tested by comparison with recorded data in Macedonia, because strong motion data is not available at epicentral distances of about $600 \mathrm{~km}$.

More detailed and comprehensive analyses of this kind will be possible only when new and abundant recordings of local and Vrancea earthquakes become available. In the meantime, it is hoped that this analysis will help motivate and guide observational programs that will contribute such needed data. Furthermore, it is hoped that our profession will abandon outdated and ill-founded methods of scaling strong motion amplitudes, as in, for example, using site classifications in terms of $V_{30}$ or A, B, C, and D, [39], and finally realize that scaling the design spectra by peak acceleration and fixed shape spectra is not conservative.

In this paper we have used the seismicity model in which earthquakes are represented by points. Such representation works well and is sufficiently accurate for general purpose mapping of seismic hazard, but it is not suitable for modeling seismic hazard for important structures (nuclear power plants, dams, major bridges, major pipe lines, and alike) when active faults are within several source dimensions from the site. When this occurs, detailed three-dimensional representation of earthquake sources must be performed so that the specific geometric relationships can be included in the attenuation models and UHS calculations. The point source representation via UHS method is also not meant for use when predicting spatial site amplification for a given nearby earthquake. For example, the 1963 Skopje earthquake produced specific distribution of strong motion amplitudes that resulted in the specific distribution of damaged buildings. This distribution was in turn influenced by the specific direction of wave arrival and subsequent interference and amplification through the three-dimensional geological structure (Appendix C). An earthquake with a different azimuth of 


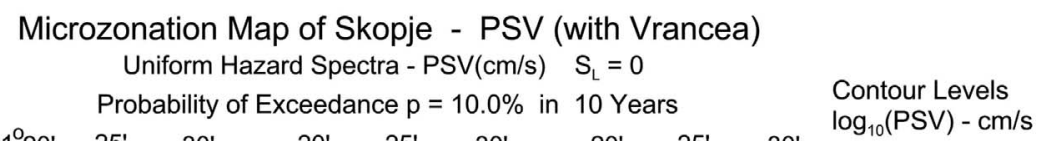

Contour Levels

$\log _{10}(P S V)-\mathrm{cm} / \mathrm{s}$
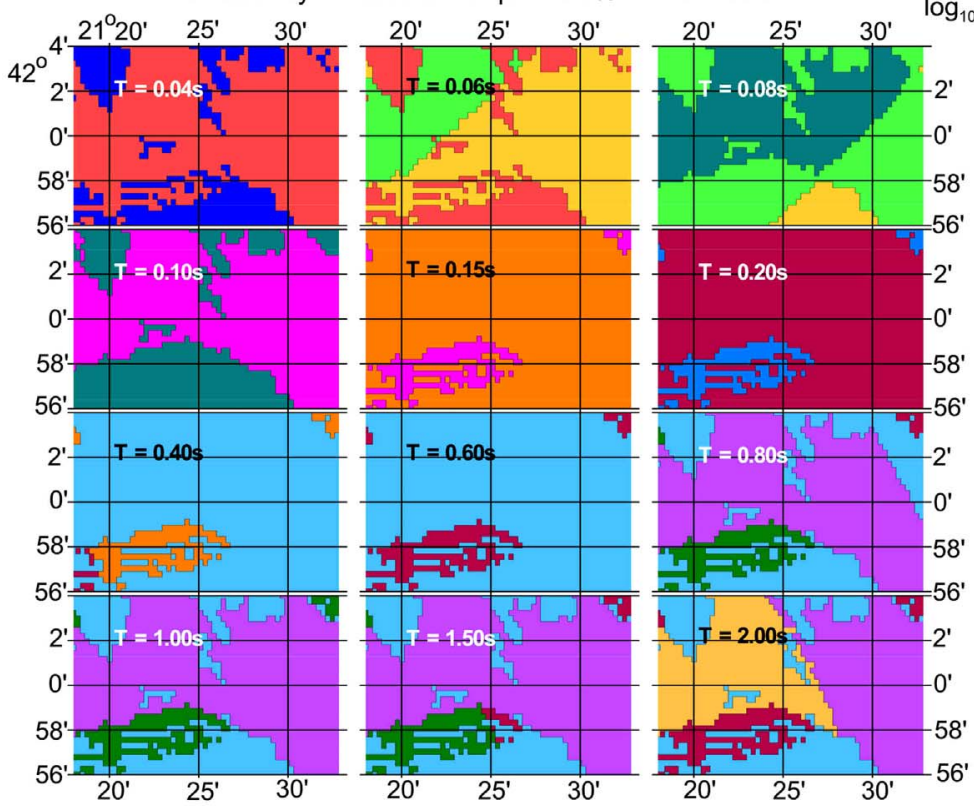

b

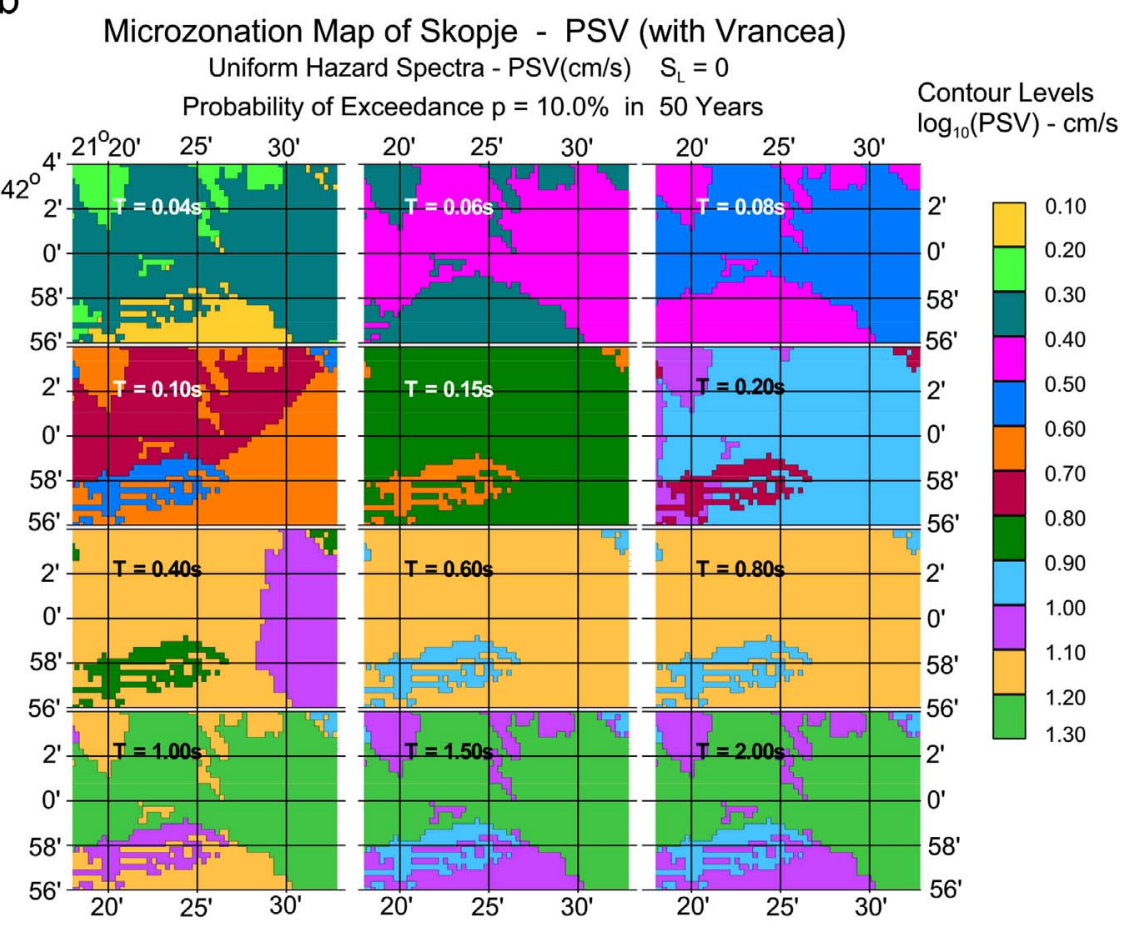

Fig. 9. a. An example of a Skopje seismic microzoning map for Pseudo Spectral Velocity (PSV) with a $5 \%$ fraction of critical damping. The map is computed with the UHS method for local seismicity and the contribution from the Vrancea earthquakes combined at the "rock" soil sites $\left(S_{L}=0\right)$, at 12 periods ranging from 0.04 to $2.00 \mathrm{~s}$, for exceedance probability of $p=0.10$ and an exposure time of $Y=10$ years. 9b. An example of a Skopje seismic microzoning map, for Pseudo Spectral Velocity (PSV), with a 5\% fraction of critical damping. The map is computed with the UHS method for local seismicity and the contribution from the Vrancea earthquakes combined at the "rock" soil sites $\left(S_{L}=0\right)$ at 12 periods ranging from 0.04 to $2.00 \mathrm{~s}$, for an exceedance probability of $p=0.10$ and an exposure time of $Y=50$ years. 9c. An example of a seismic microzoning map for Skopje, for Pseudo Spectral Velocity (PSV), for a 5\% fraction of critical damping. The map is computed using the UHS method for local seismicity and the contribution from the Vrancea earthquakes combined, at stiff soil sites $\left(S_{L}=1\right)$, at 12 periods ranging from 0.04 to $2.00 \mathrm{~s}$, for an exceedance probability of $p=0.10$ and an exposure time of $Y=10$ years. 9d. An example of a seismic microzoning map for Skopje, for Pseudo Spectral Velocity (PSV), for a 5\% fraction of critical damping. This map is computed with the UHS method for local seismicity and contribution from the Vrancea earthquakes combined, at the stiff soil sites $\left(S_{L}=1\right)$, at 12 periods ranging from 0.04 to $2.00 \mathrm{~s}$, for an exceedance probability of $p=0.10$ and an exposure time of $Y=50$ years. 
a

Microzonation Map of Skopje - PSV (with Vrancea)

Uniform Hazard Spectra - PSV $(\mathrm{cm} / \mathrm{s}) \quad \mathrm{S}_{\mathrm{L}}=1$

Probability of Exceedance $p=10.0 \%$ in 10 Years Contour Levels

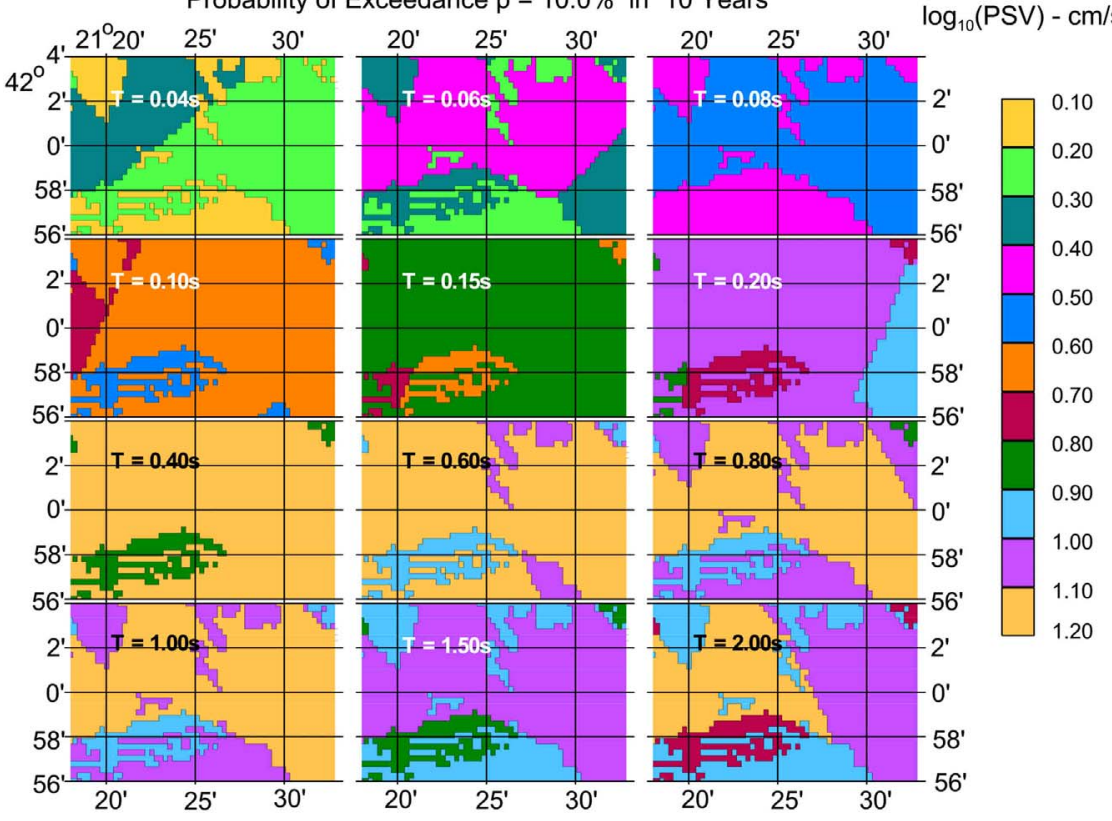

b
Microzonation Map of Skopje - PSV (with Vrancea)
Uniform Hazard Spectra - PSV $(\mathrm{cm} / \mathrm{s}) \quad S_{L}=1$
Probability of Exceedance $p=10.0 \%$ in 50 Years
Contour Levels
$\log _{10}(P S V)-\mathrm{cm} / \mathrm{s}$
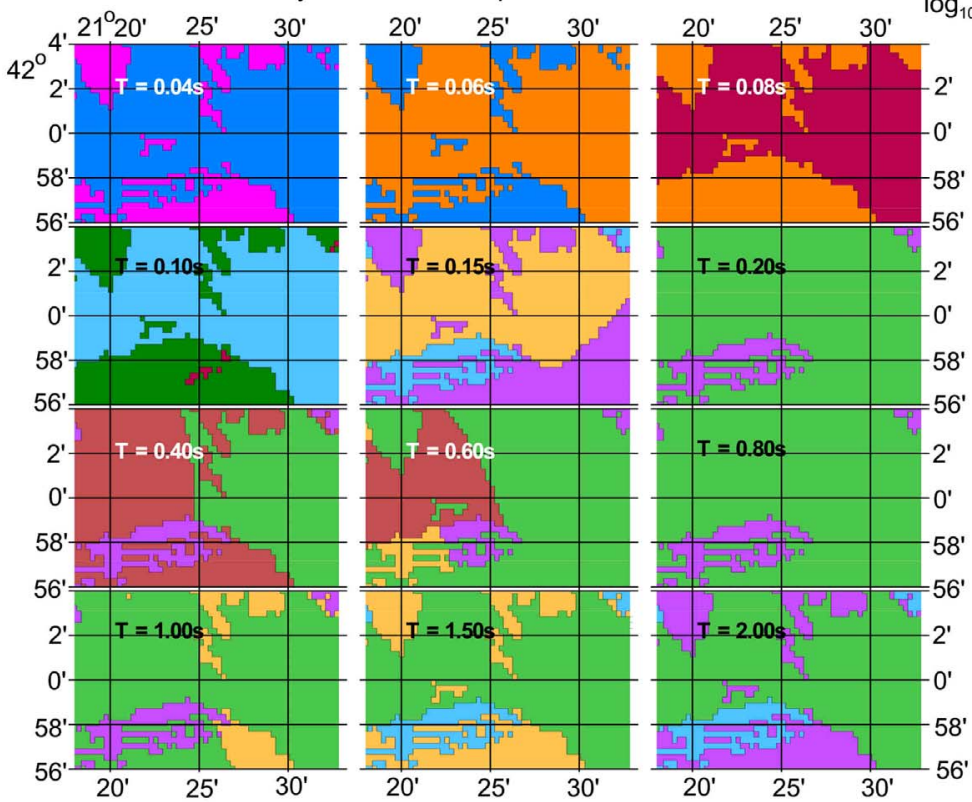

Fig. 9. (continued)

arriving waves will produce a very different pattern of strong motion amplitudes and the resulting damage to structures. The spatial variations of strong motion amplitudes that we illustrate in this paper represent a distribution based on all possible outcomes from a very large number of such individual events, which are then described by the UHS amplitudes. A scenario for which a deterministic description of design spectra will offer a more robust representation of what can be expected from future earthquakes would be the case in which the hazard is dominated by a single well-known fault system, of which enough is known to be able to predict the largest possible events and its all other governing variables.

A refinement of the point source representation is possible in terms 

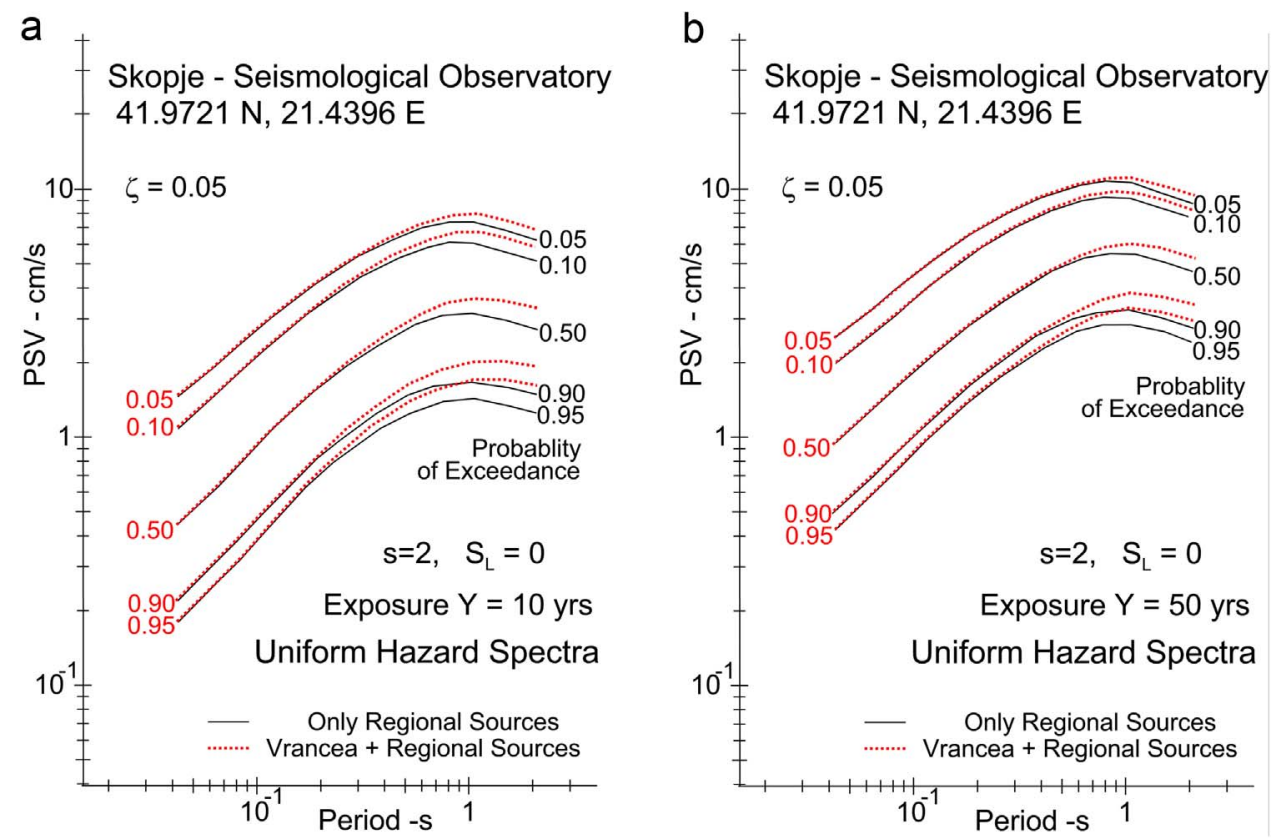

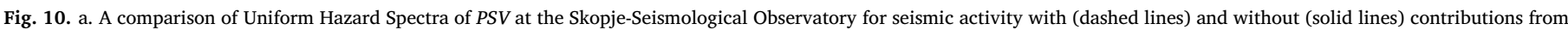

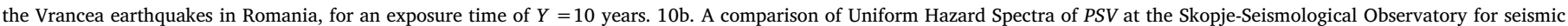
activity with (dashed lines) and without (solid lines) contributions from the Vrancea earthquakes in Romania, for an exposure time of $Y=50$ years.
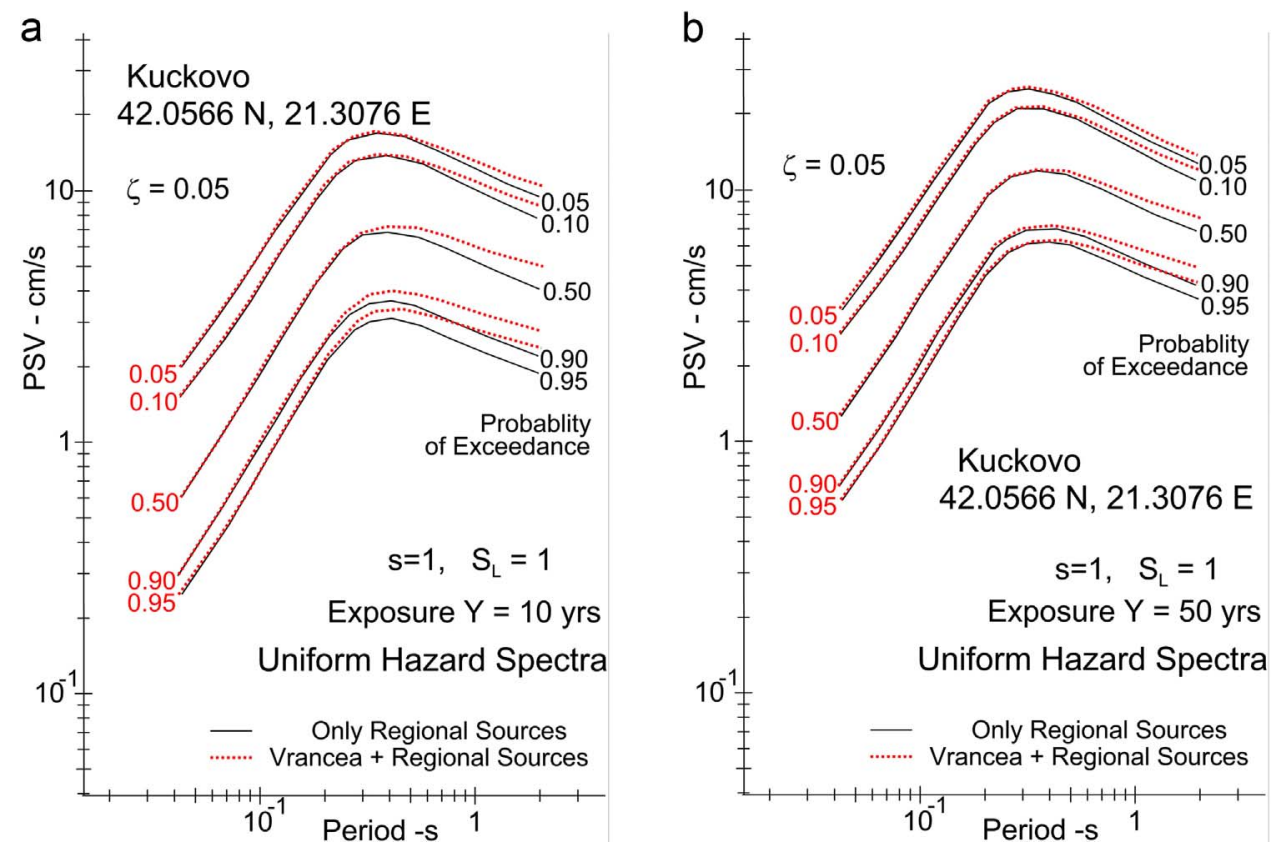

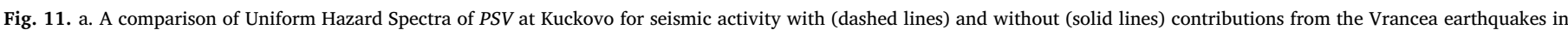

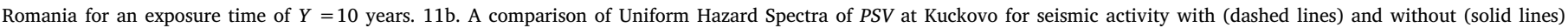
contributions from the Vrancea earthquakes in Romania for an exposure time of $Y=50$ years.

of line sources [43] when such information is available to accompany seismic activity rates and data on maximum magnitudes. This information was not available in sufficiently detailed and complete form for the seismicity surrounding Skopje and was therefore not used in the examples presented in this paper.

\section{Acknowledgments}

Research work of the third author was supported in part by the Serbian Ministry of Education, Science, and Technology Development Grant no. 36043. 
a

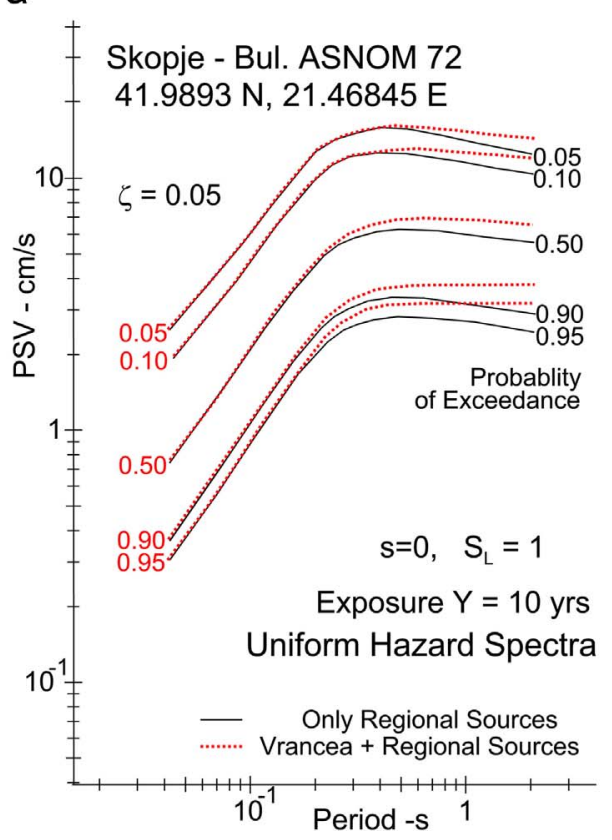

b

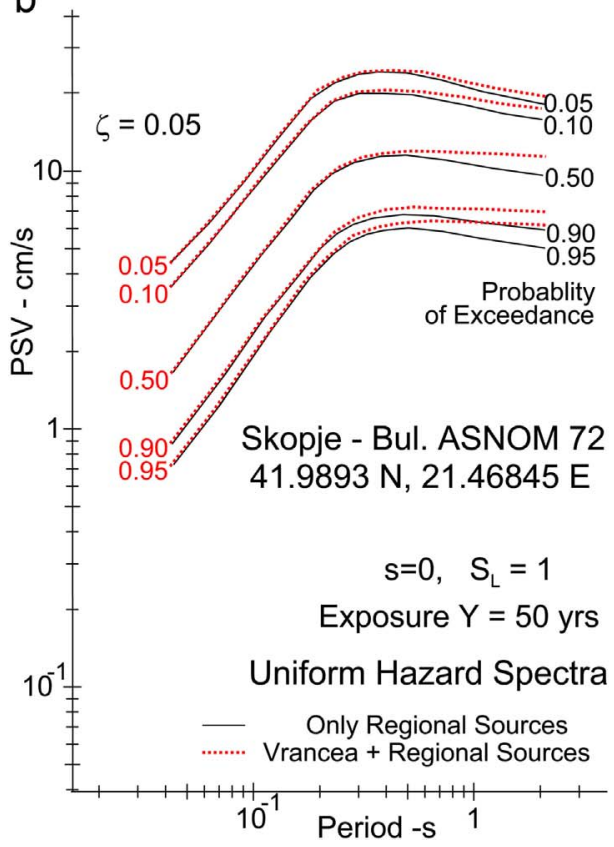

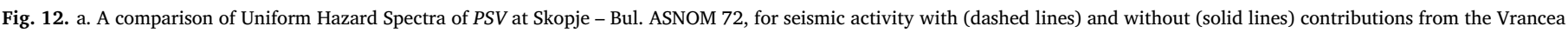

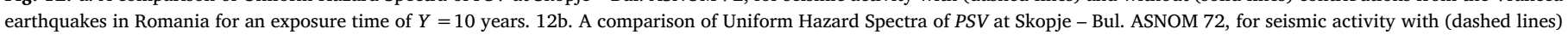
and without (solid lines) contributions from the Vrancea earthquakes in Romania for an exposure time of $Y=50$ years.

\section{Appendix A. - Seismic activity and seismicity model}

To illustrate computations for the strong motion earthquake hazard, we briefly summarize the data on seismic activity surrounding investigated locations and procedures for deriving the relevant seismicity model. The earthquake activity in the region is assumed to be well represented by a catalog compiled by merging records listed in the following catalogs:

- the BSHAP2 catalog (510 BCE-2012) that was compiled during the BSHAP2 NATO-funded project by seismologists from Albania, Croatia, Macedonia, Montenegro, Serbia, and Turkey [49];

- the ISC-catalog (2013-2014) (http://www.isc.ac.uk).

If not reported as such, all magnitudes were converted to moment magnitudes $\left(M_{w}\right)$ using regionally adjusted regressions between $M_{w}$ on one side and $M_{S}, M_{L}$, or $m_{b}$ on the other [49]. The catalog was declustered using time-space windows, the size of which depended on the mainshock's magnitude as described, for example, in Herak et al. [17], thus removing dependent events (foreshocks and aftershocks). In estimating recurrence parameters, only mainshocks with magnitude exceeding 3.4 were considered. Fig. A1 shows the geographical distribution of the earthquake epicenters.

Seismic activity is described by the earthquake occurrence rate in terms of moment magnitude $\left(M=M_{w}\right)$, assuming the validity of the truncated Gutenberg-Richter recurrence relation:

$N(M)=\left\{\begin{array}{cc}10^{a-b M} & M_{\min } \leq M \leq M_{\max } \\ 0 & \text { otherwise }\end{array}\right.$

where $N(M)$ is the number of events with magnitudes greater than or equal to $M$, and $M_{\min } \leq M \leq M_{\max }$ is the allowable range of magnitudes. $M_{\min }$ varies in space and time according to the completeness of the contributing catalog(s), and the distribution of $M_{\max }$ (Fig. A2) is assumed by taking into account the magnitudes and intensities of the largest historical earthquakes and the lengths of the known major fault segments. The spatial and temporal completeness of the catalog (see Fig. A3 for examples) was estimated as proposed by Herak et al. [17] (for details, see also [18,19]).

The seismicity of the region was modeled using a variant of the distributed smoothed seismicity approach [e.g., Frankel [12] and Frankel et al. [13]; see also Lapajne et al. [29] who applied it to model the seismicity of Slovenia]. This method was also used to compile the earthquake hazard maps for Croatia [16], which are adopted as base maps in the National Annex to EC8 [20]. For computations, the region is divided into a mosaic of rectangular cells $\left(0.1^{\circ} \times 0.1^{\circ}\right.$, or approximately $\left.11.1 \times 11.1=123 \mathrm{~km}^{2}\right)$. For each cell, parameters $a$ and $b$ in Eq. (A.1), along with their uncertainties, are calculated taking the magnitude completeness thresholds into account. Parameter $b$ is estimated using the maximum-likelihood algorithm of Weichert [84], which considers only earthquakes above their respective completeness thresholds within the smallest circle centered in each of the cells that holds at least 40 such events. The resulting spatial distribution of the $b$-value is shown in Fig. A2. $a$ is assessed by counting the number of events $\mathrm{N}_{1}=\mathrm{N}(M \geq 3.5), \mathrm{N}_{2}=\mathrm{N}(M \geq 3.8), \mathrm{N}_{3}=\mathrm{N}(M \geq 4.2)$ within the circle that occurred after the corresponding onset of complete reporting. For each $\mathrm{N}_{\mathrm{i}}, \mathrm{N}_{0 \mathrm{i}}(b)=10^{a}$ is estimated using Eq. (A.1), and representative $a$ is obtained by taking the logarithm of the average. The seismicity rates thus obtained are normalized to one year and to an area of $10,000 \mathrm{~km}^{2}$. After $a$-values were assigned to each of the grid-cells, the resulting spatial distribution is smoothed using a bivariate, normal-elliptical smoothing kernel (for an example, see e.g., [29]), with the major axis directed along the predominant fault strike within the corresponding source zone whenever it is known. Here we extracted such information from the database of 


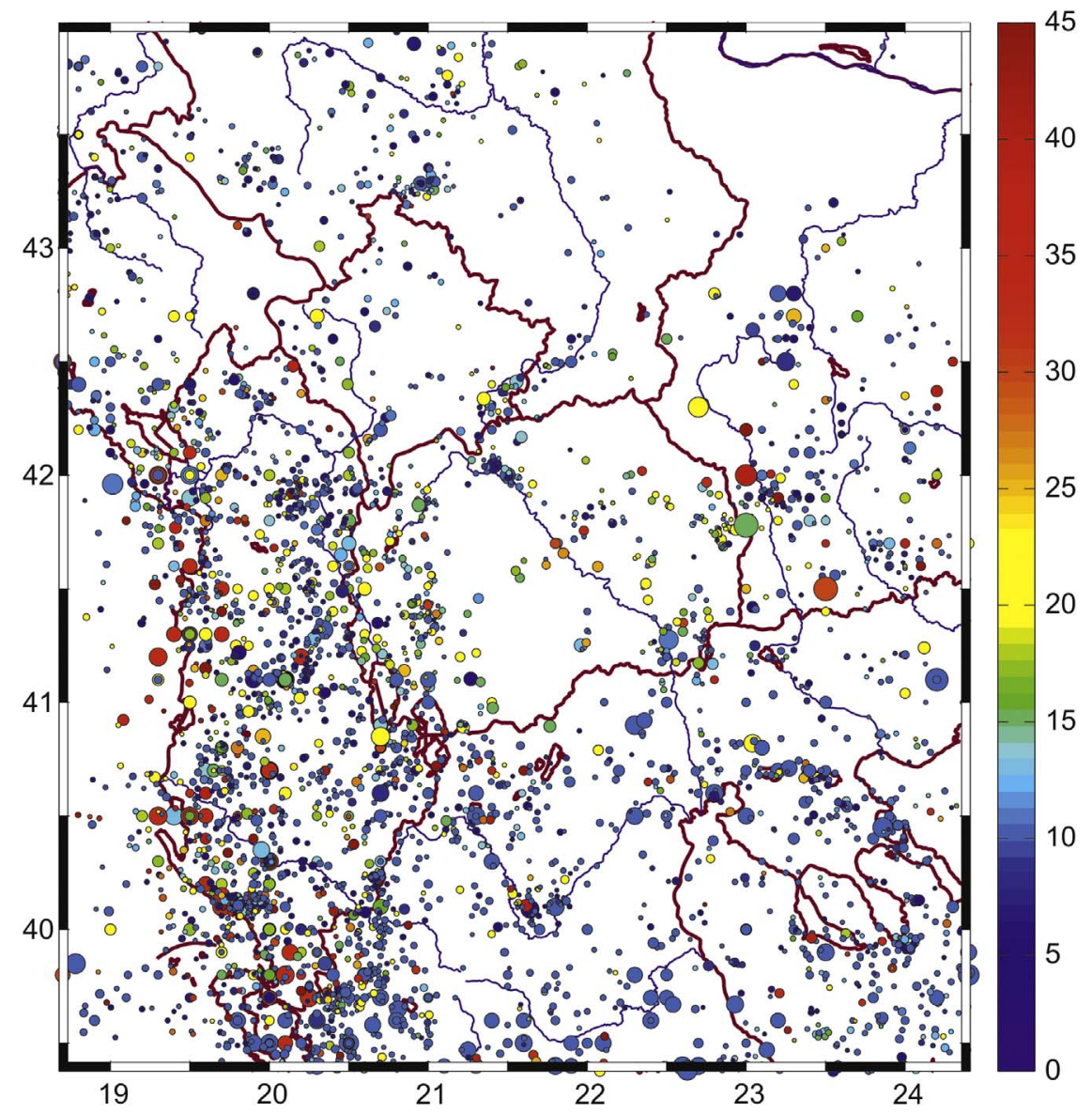

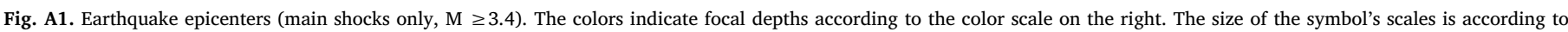
magnitude.

seismogenic faults, which is one of the products of the SHARE-project ([8], http://diss.rm.ingv.it/share-edsf/) that also lists the corresponding predominant style of faulting (normal, reverse, strike-slip). If the predominant strike was unknown, circular Gaussian smoothing was applied. The widths of Gaussian distribution (standard deviations) along the major and minor axes are scaled to the expected maximum fault length and to the width of the surface projection of the fault plane, respectively, estimated for the corresponding $M_{\max }$ in the cell by relations of Wells and Coppersmith [85]. In this way, the seismogenic potential estimated on the basis of past earthquakes that occurred in the neighborhood of each of the grid-cells, is distributed along the known faults systems. The seismicity model is then defined for each of the cells by the following parameters:

- geographical coordinates of the cell center,

- $a$-value, and its standard deviation,

- $b$-value, and its standard deviation,

- maximum moment magnitude, $M_{\max }$

- average focal depth $(\mathrm{km})$, and its standard deviation,

- predominant strike of the seismogenic faults $\left({ }^{\circ}\right)$, and its standard deviation,

- predominant style of faulting (unknown, normal, reverse, strike-slip).

Our seismicity model is mostly based on the past seismicity record. It does not explicitly consider fault sources, as we feel that necessary data on positions of seismogenic faults, their segmentation, geometry, Quaternary activity rates, and so forth, are still far from reliably known and complete. Nevertheless, as previously noted, the model includes some of the fault-specific data (predominant strike, the style of faulting, lengths of some known segments) when such data were available.

\section{Appendix B. - Seismicity of the Vrancea source zone}

The Vrancea earthquakes in Romania occur near a sharp bend of the southeastern Carpathians [21]. The seismicity is concentrated in a highvelocity focal volume in the depth range from about $60-200 \mathrm{~km}[53,61]$. At shallower depths (0-60 km), earthquakes occur sporadically and are not large, with magnitude typically below 5.5. Source properties of large Vrancea earthquakes and the geology of the surrounding areas generally lead to elongation of the intensity contours toward the southwest and Serbia and Macedonia. This is illustrated in Fig. 3 by the intensity contours of the 1977 earthquake [28]. The cities in Macedonia were at considerable epicentral distances from this Vrancea earthquake, from 550 to $730 \mathrm{~km}$ (Stip - 598 ; 

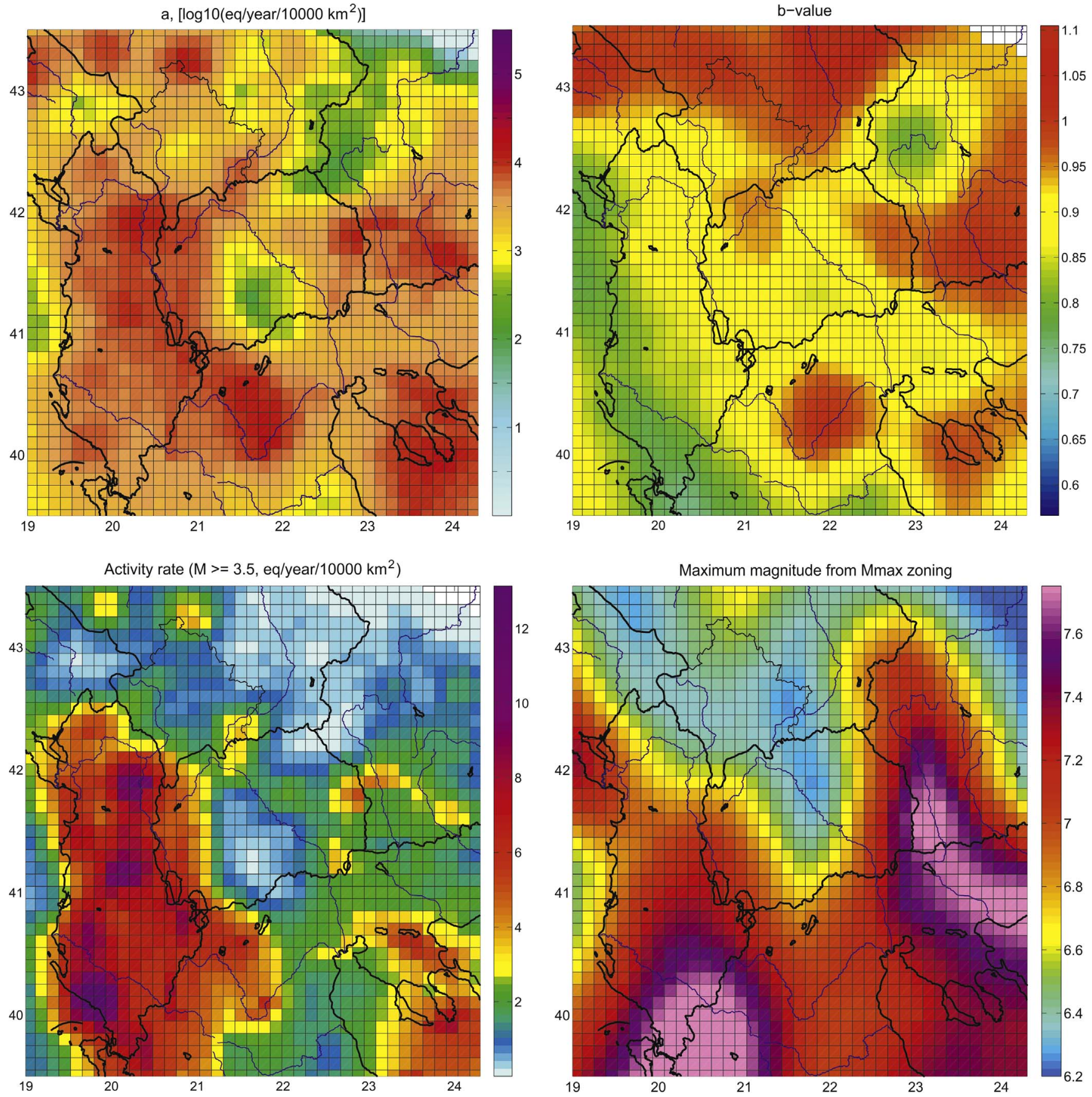

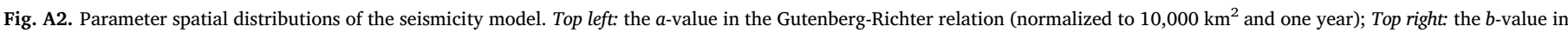
the Gutenberg-Richter relation; Bottom left: the activity rate for $\mathrm{M} \geq 3.5$ (the number of events normalized to one year and $10,000 \mathrm{~km}^{2}$ ); Bottom right: maximum magnitude, $M_{\text {max }}$.

Skopje - 619; Ohrid - 726 km). In the March 4, 1977 earthquake, Stip was in zone V (MSK scale), while Skopje and Ohrid were in zone IV.

Historical data on Vrancea earthquake occurrences have been compiled by Radu [57] and Purcaru [55]. The corresponding Gittenberg-Richter trend $\log _{10} N=a-b M$, which describes the number of earthquakes $N$ per year greater or equal to a magnitude $M$, has been studied by many authors. Here we mention Radulian et al. [56] who give $a=4.77 \pm 0.24$ and $b=0.89 \pm 0.04$; Wenzel et al. [83] and Oncescu et al. [51] who give $a=4.10$ and $b=0.78$; and Paskaleva [52] who give us $a=4.21$ and $b=0.80$. The associated estimates of the largest possible magnitude for the Vrancea events range from 7.8 to 8.1. In Fig. B1 we also reproduce the observed values of $N$ versus $M$ for the period between 1980 and 1997 (redrawn from [51]). For the calculations in this paper, we assumed $a=4.10 \pm 0.24, b=0.78 \pm 0.04$, and that $M_{\max }$ is uniformly distributed between 7.9 and 8.1 .

\section{Appendix C. - 1963 Skopje Earthquake}

To provide additional background on seismic activity in Skopje, Macedonia, we include this appendix and selected references that describe the effects of the 1963 earthquake. Of particular interest is the report prepared by the UNESCO team of experts, who visited the area and reported on their findings in "The Skopje Earthquake 1963" [82]. 

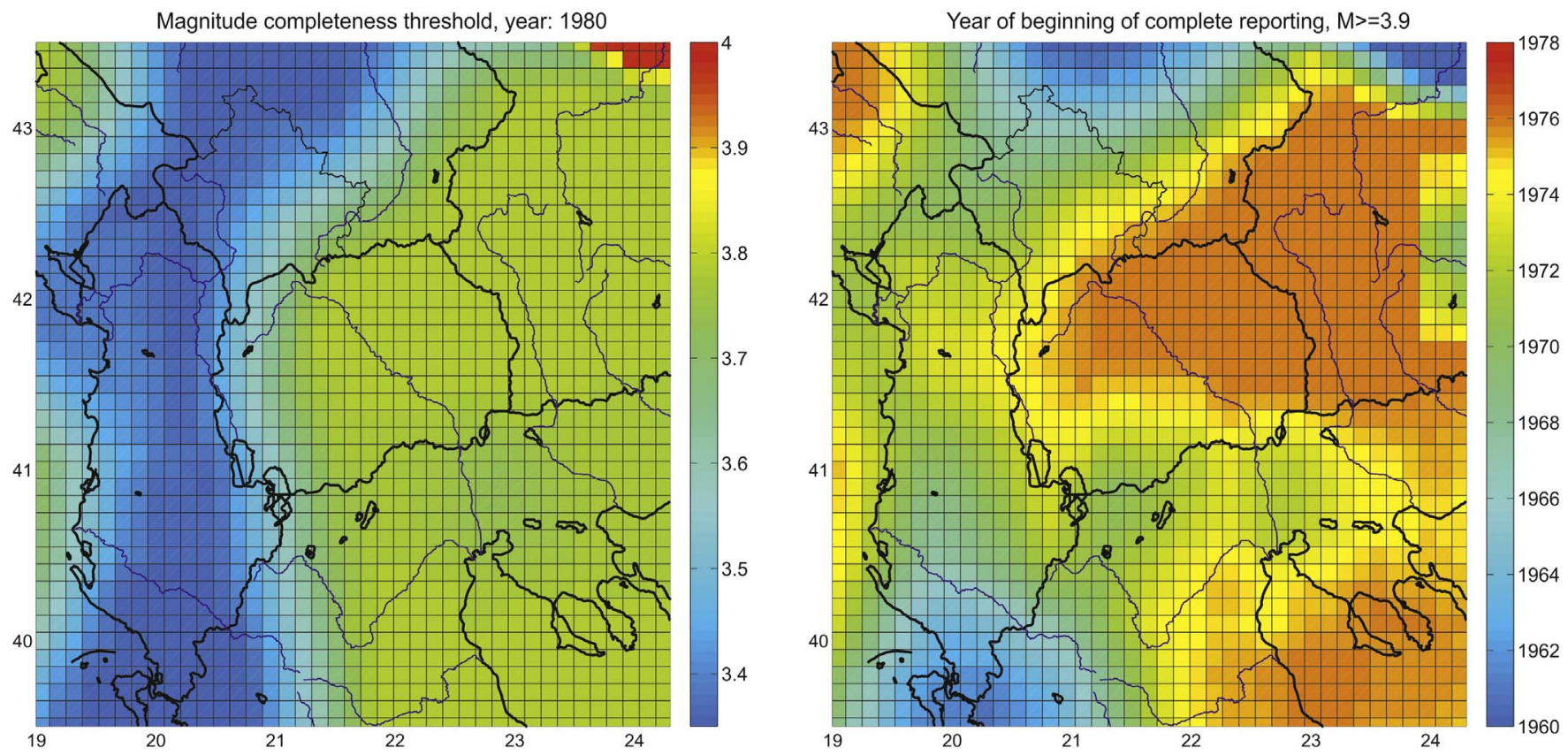

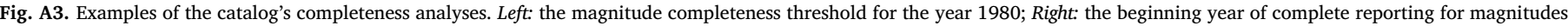
$\geq 3.9$.

The earthquake of July 26, 1963 was felt over an area of 200,000 square kilometers. It killed 1070 people, wounded 3,330, and caused major damage. The epicentral intensity was IX on the MCS scale, it released energy of $10^{21}$ ergs, and its magnitude was reported as $\mathrm{M}=6.1$. There were no strong motion accelerographs operating at the time so the amplitudes and time characteristics of strong motion were not recorded. The focal mechanism was associated with NNW-SSE dilatation and ENE- WSW compression [87].

By an inverse analysis of ground motions, and using simulations based on simple rectangular fault and converting the computed ground motion velocities into intensities, Suhadolc et al. [60] described the best fit of the reported intensities. These were associated with a rectangular fault $15 \times 8 \mathrm{~km}$, with strike $298^{\circ}$, dip $79^{\circ}$, and rake $22^{\circ}$, with the top of the fault at $2 \mathrm{~km}$ below ground surface, a nucleation point at $9-\mathrm{km}$ depth that spread bilaterally from focus, and with $\mathrm{M}=5.9$. The position of the horizontal projection of their fault model is shown in Fig. C1 by dashed lines.

The zones marked I through IV in Fig. C2 outline the areas with different degrees of building damage [54,86]. The heaviest damage occurred in the city center and south of the Skopje Zoo (see the two zones of heavy damage in Fig. C1 marked as I). Most of the buildings in the new city (south of river Vardar) were of brick masonry type, with heights up to 6 stories. Most of the destroyed buildings were of this type.

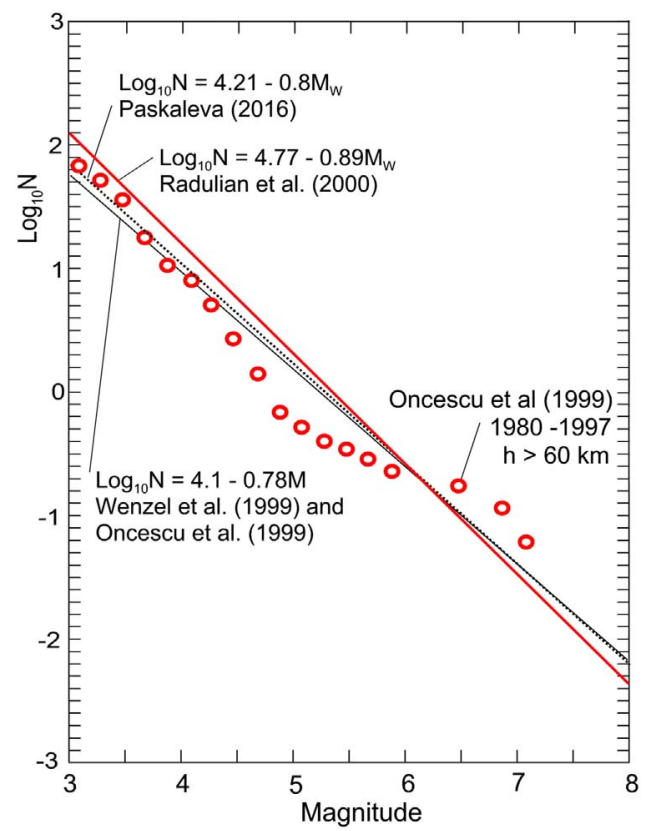

Fig. B1. The number of earthquakes greater or equal to $M$ per year in the Vrancea source zone in Romania. 


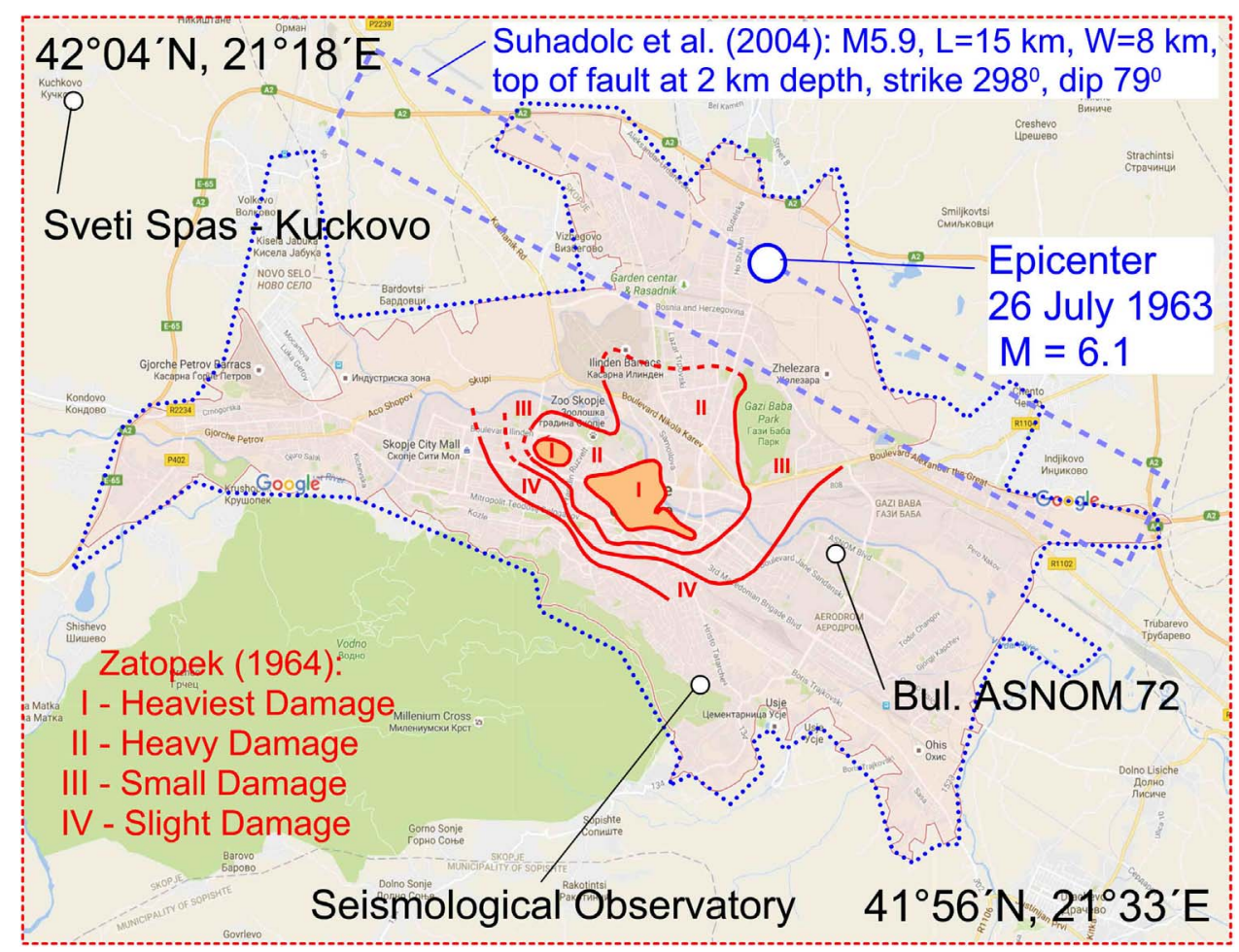

Fig. C1. A horizontal projection of the proposed fault plane for the July 26, 1963 earthquake (dashed rectangle, Suhadolc 2004), earthquake epicenter, and the areas of damaged buildings in Skopje [86].

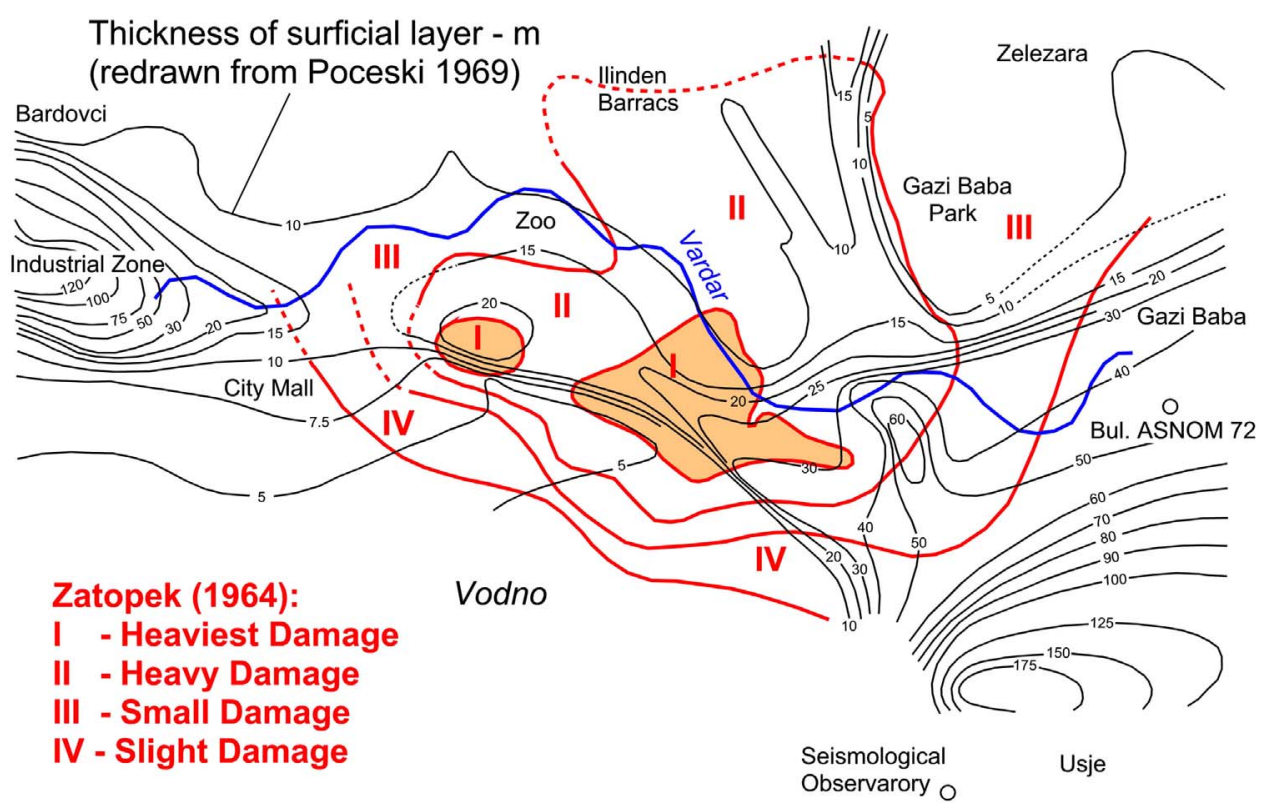

\section{SKOPJE EARTHQUAKE - 26 July 1963}

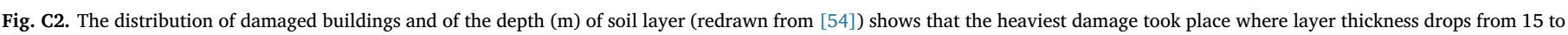
$20 \mathrm{~m}$ down to 7.5 and $5 \mathrm{~m}$.

Poceski [54] noted that the zone of heaviest damage coincides with an abrupt change of the soil layer thickness from about $20 \mathrm{~m}$ down to 5-7.5 m. It appears that the waves arriving from north-northeast were amplified by a progressive decrease in the layer thickness and by interference with reflected waves from the abrupt end of the layer. This type of amplification of strong ground motion is common and has resulted in increased damage during many other earthquakes (e.g., [80,11,22]).

\footnotetext{
${ }^{1}$ Can be downloaded from http://home.iitk.ac.in/ vinaykg/iset.html.

* Can be downloaded from http://www.usc.edu/dept/civil_eng/Earthquake_eng/.
} 


\section{References $^{1,}$}

[1] Nauk Akademia, SSSR. Seismicheskoe Reionirovanie Teritorii SSSR. Moskva: IzdatelstvoNauka; 1980.

[2] Anderson JG, Trifunac MD. Uniform risk functionals for characterization of strong earthquake ground motion. Bull Seism Soc Am 1978;68:205-18.

[3] Anderson JG, Trifunac MD. Application of Seismic Risk Procedures to Problems in Microzonation, In: Proceedings of the Second International Conference on Microzonation, San Francisco, 559-569; 1978b.

[4] Basic geological map - Kačanik. Basic geological map - Kačanik, K34-67 (in Macedonian: Основна геолошка карта на СФРЈ, КАЧАНИК, К34-67), Geological Institute, Skopje (Геолошки завод-Скопје), Institute for Research of Mineral Raw Materials (ООРЗ Институт за истражување на минерални суровини) Geological Institute, Belgrade (RO Geološki institut, Beograd), editorial and publication of the Federal Geological Institute of Belgrade (Savezni geološki zavod, Beograd); 1984.

[5] Basic geological map - Kumanovo. Basic geological map - Kumanovo, K34-68 (in Macedonian: Основна геолошка карта на СФРЈ, КУМАНОВО, К34-68), Geological Institute, Skopje (Геолошкиот завод Скопје), editorial and publication of the Federal Geological Institute of Belgrade (Savezni geološki zavod, Beograd); 1973.

[6] Basic geological map - Skopje. Basic geological map - Skopje, K34-79 (in Macedonian: Основна геолошка карта на СФРЈ, СКОПЈЕ, К34-79), Geological Institute, Skopje (Геолошкиот завод Скопје), editorial and publication of the Federal Geological Institute of Belgrade (Savezni geološki zavod, Beograd); 1983.

[7] Basic geological map - Titov Veles. Basic geological map - Titov Veles, K34-80 (in Macedonian: Основна геолошка карта на СФРЈ, ТИТОВ ВЕЛЕС, К34-80), Geological Institute, Skopje (Геолошкиот завод Скопје), editorial and publication of the Federal Geological Institute of Belgrade (Savezni geološki zavod, Beograd); 1980.

[8] Basili R, Kastelic V, Demircioglu MB, Garcia Moreno D, Nemser ES, Petricca P, Sboras SP, Besana-Ostman GM, Cabral J, Camelbeeck T, Caputo R, Danciu L, Domac H, Fonseca J, García-Mayordomo J, Giardini D, Glavatovic B, Gulen L, Ince Y, Pavlides S, Sesetyan K, Tarabusi G, Tiberti MM, Utkucu M, Valensise G, Vanneste K, Vilanova S, Wössner J. The European Database of Seismogenic Faults (EDSF) compiled in the framework of the Project SHARE. 〈http://diss.rm.ingv.it/shareedsf/>, doi: 10.6092/INGV.IT-SHARE-EDSF; 2013.

[9] Electronic Official Gazette of the City of Skopje. Decision on adoption of the General Urban Plan of the City of Skopje 2012-2022, Edition for the December 06, 2012, Electronic Official Gazette of the City of Skopje, Year 2012, No. 18; 2012.

[10] Eurocode 8. Design provisions of structures for earthquake resistance - Part 1: General rules, seismic actions and rules for buildings (EN1998-1) / CEN Techn. Comm. 250 - SC8, CEN, Brussels; 2005.

[11] Faik-Kara H, Trifunac MD. Two-dimensional earthquake vibrations in sedimentary basins - SH waves. Soil Dyn Earthq Eng 2014;63:69-82.

[12] Frankel A. Mapping seismic hazard in the central and eastern United States. Seism Res Lett 1995;66:8-21.

[13] Frankel A, Mueller C, Barnhard T, Leyendecker E, Wesson R, Harmsen S, Klein F, Perkins D, Dickamn N, Hanson S, Hopper M. USGS national seismic hazard maps. Earthq Spectra 2000;16:1-20.

[14] Gubin IE. On some questions of seismic regionalization, Akad. Nauk SSSR, Trudy Geofizicheskogo Instituta, 25(152); 1954. p. 36-73.

[15] Gupta ID, Trifunac MD. Order statistics of peaks in earthquake response. J Eng Mech ASCE, EMD 1988;114(10):1605-27.

[16] Herak M. et al. Republika Hrvatska, Karta potresnih područja, http://seizkarta.gfz. hr; 2011.

[17] Herak D, Herak M, Tomljenović B. Seismicity and focal mechanisms in NorthWestern Croatia. Tectonophysics 2009;465:212-20. http://dx.doi.org/10.1016/j. tect.2008.12.005.

[18] Herak M, Herak D, Markušić S. Revision of the earthquake catalogue and seismicity of Croatia, 1908-1992. Terra Nova 1996;8/1:86-94.

[19] Herak M, Herak D. Analyses of seismicity as input for earthquake hazard studies in Bosnia and Herzegovina. [Chapter 1]. Selected topics in earthquake engineering from earthquake source to seismic design and hazard mitigation. Banja Luka, Republic of Srpska: ZIBL; 2009. p. 1-24.

[20] Hrvatski zavod za norme (2011): HRN EN 1998-1:2011/NA. Eurokod 8: Projektiranje potresne otpornosti konstrukcija - 1. dio: Opća pravila, potresna djelovanja i pravila za zgrade - Nacionalni dodatak (Eurocode 8: Design of structures for earthquake resistance - Part 1: General rules, seismic actions and rules for buildings - Natl.1 Annex); 2011.

[21] Ismail-Zadeh AT, Panza GF, Naimark BM. Stress in the Descending Relic Slab beneath the Vrancea Region,. Romania, Pure Appl Geophys 2000;157:111-30.

[22] Jalali RS, Tokmechi Z, Trifunac MD. A note on surface motion of a semi-cylindrical alluvial valley for incident-cylindrical SH waves radiating from a fault with arbitrary orientation. Soil Dyn Earthq Eng 2015;79:80-8.

[23] Jordanovski LR, Lee VW, Manić MI, Olumčeva T, Sinadinovski C, Todorovska MI, Trifunac MD. Strong earthquake ground motion data in EQINFOS: Yugoslavia, Part I. Los Angeles, CA: Civil Eng. Report CE 87-05, Univ. of Southern California; 1987.

[24] Kanai K. Semi-empirical formula for the seismic characteristics of the ground. Bull Earthq Res Inst Tokyo 1957;35:309-25.

[25] Kanai K. The requisite conditions for predominant vibration of ground. Bull Earthq Res Inst Tokyo 1957;35:457-71.

[26] Kanai K. Engineering seismology. Tokyo, Japan: Univ. of Tokyo Press; 1983.

\footnotetext{
${ }^{1}$ Can be downloaded from http://home.iitk.ac.in/ vinaykg/iset.html.

* Can be downloaded from http://www.usc.edu/dept/civil_eng/Earthquake_eng/.
}

[27] Karnik V. Microzoning Programme within the UNDP-UNESCO Survey of Seismicity of Balkan Region. In: Proceedings Microzonation Conference, Seattle, Washington, I, 213-215; 1972

[28] Kronrod T, Radulian M, Panza G, Popa M, Paskaleva I, Radovanovich S, Gribovszki K, Sandu I, Pekevski L. Integrated transnational macroseismic data set for the strongest earthquakes of Vrancea (Romania). Tectonophysics 2013;590:1-23.

[29] Lapajne J, Šket Motnikar B, Zupančič P. Probabilistic seismic hazard assessment methodology for distributed seismicity. Bull Seism Soc Am 2003;93:2502-15.

[30] Lee VW. Pseudo relative velocity spectra in former Yugoslavia. Eur J Earthq Eng 1995; VII(1):12-22.

[31] Lee VW. Discussion: prediction of horizontal response spectra in Europe. Int J Earthq Eng Struct Dyn 1997;26(2):289-93.

[32] Lee VW. ${ }^{1}$ Empirical scaling of strong earthquake ground motion: part I: attenuation and scaling of response spectra. ISET J Earthq Tech 2002;39(4):219-54.

[33] Lee VW. ${ }^{1}$ Empirical scaling and regression methods for earthquake strong-motion spectra-a review. ISET J 2007;44(1):39-69.

[34] Lee VW, Manić MI. Empirical scaling and regression methods for strong earthquake ground motions in Yugoslavia—a review. Izgradnja 2009;63(5-6):234-57.

[35] Lee VW, Trifunac MD. * Uniform risk spectra of strong earthquake ground motion. Los Angeles, California: Department of Civil Engineering, Report CE 85-05, University of Southern Calif.; 1985.

[36] Lee VW, Trifunac MD. * Microzonation of a metropolitan area. Los Angeles, California: Department of Civil Engineering, Report CE 87-02, University of Southern California; 1987.

[37] Lee VW, Trifunac MD. Frequency dependent attenuation of strong earthquake ground motion in Yugoslavia. Eur Earthq Eng 1992;VI(1):3-13.

[38] Lee VW, Trifunac MD. Empirical scaling of Fourier amplitude spectra in former Yugoslavia, with V.W. Lee. Eur Earthq Eng 1993;VII(2):47-61.

[39] Lee VW, Trifunac MD. Should average shear wave velocity in the top $30 \mathrm{~m}$ of soil be the only local site parameter used to describe seismic amplification? Soil Dyn Earthq Eng 2010;30(11):1250-8.

[40] Lee VW, Trifunac MD. Seismic hazard maps in Serbia, submitted for publication; 2017.

[41] Lee VW, Trifunac MD. Seismic hazard maps in Macedonia, submitted for publication; 2017.

[42] Lee VW, Herak M, Herak D, Trifunac MD. Uniform hazard spectra in Northwestern Bosna and Hercegovina. Izgradnja 2010;64(5-6):282-304.

[43] Lee VW, Herak M, Herak D, Trifunac MD. Uniform hazard spectra in western Balkan Peninsula. Soil Dyn Earthq Eng 2013;55:1-20.

[44] Lee VW, Trifunac MD, Herak M, Herak D. Uniform hazard earthquake acceleration spectra in Kraljevo - contributions from local seismicity. Izgradnja 2011;65(5-6):227-35.

[45] Lee VW, Trifunac MD, Herak M, Herak D. Minimum radius of seismic activity for earthquake hazard analyses. Izgradnja 2011;65(5-6):219-26.

[46] Lee VW, Trifunac MD, Bulajić B, Manić M. A preliminary empirical model for frequency-dependent attenuation of Fourier amplitude spectra in Serbia from the Vrancea earthquakes. Soil Dyn Earthq Eng 2016;83:167-79.

[47] Lee VW, Trifunac MD, Bulajić B, Manić M. Preliminary empirical scaling of pseudorelative velocity spectra in Serbia from the Vrancea earthquakes. Soil Dyn Earthq Eng 2016;86:41-54.

[48] Liao ZP. Seismic microzonation in China. Inst Eng Mech State Seismol Bur 1985:1-37.

[49] Markušić S, Gülerce Z, Kuka N, Duni L, Ivančić I, Radovanović S, Glavatović B, Milutinović Z, Akkar S, Kovačević S, Mihaljević, Šalić J iR. An updated and unified earthquake catalogue for the Western Balkan Region. Bull Earthq Eng 14 2016;2:321-43.

[50] Medvedev SV. Inzenernaya Seizmologiya,Seizmologiya, Akademia Nauk SSSR Inst. FizikiInst Fiz ZemliZemli, Moskva, Mosk; 1962.

[51] Oncescu MC, Marza VI, Rizescu M, Popa M. The Romanian earthquake catalogue between 1984-1997. In: Wenzel F, Lungu D, Novak O, editors. Vrancea Earthquakes: Tectonics, Hazard and Risk Mitigation. Dordrecht: Kluwer; 1999. p. 43-7.

[52] Paskaleva I. Personal communication; 2016

[53] Pavel F. New developments in the evaluation of seismic hazard for Romania, 〈http://ccers.utcb.ro/images/noutati/Seismic_Hazard_Presentation_Workshop_ Wada_Sensei.pdf $\rangle ; 2014$.

[54] Poceski A. The ground effects of he Skopje July 1963 earthquake. Bull Seism Soc Am 1969;59(1):1-22.

[55] Purcaru G. The Vrancea, Romania, earthquake of March 4, 1977 - a quite successful prediction. Phys Earth Planet Inter 1979;18:274-87.

[56] Radulian M, Mandrescu N, Panza GF, Popescu E, Utale A. Characterization of seismic zones in Romania. Pure Appl Geophys 2000;157:57-77.

[57] Radu C. Contribution a l'etude de la seismicite de la Romanie at comparaison avec la seismicite de sud-est de la France. [Ph.D. Thesis]. Universite de Strasbourg; 1974. p. 404.

[58] Richter CF. Seismic regionalization. Bull Seism Soc Am 1959;49:123-62.

[59] Šalić B, Milutinović ZV, Garevski MD. Results achieved and improvements needed in the field of seismic hazard assessment of Republic of Macedonia. In: Proceedings of the 15 World Conference On Earthquake Enginering, Lisboa, Portugal; 2012.

[60] Suhadolc P, Sandron D, Fitzko F, Costa G. Seismic ground motion estimates for the M6.1 earthquake of July 26, 1963 at Skopje, Republic of Macedonia. Acta Geod Geophys Hung 2004;39(2-3):319-26.

[61] Telesca L, Alcaz V, Sandu I. Analysis of 1978-2008 crustal and sub-crustal earthquake catalog of Vrancea region. Nat Hazards Earth Syst Sci 2013;12:1321-5.

[62] Todorovska MI, Trifunac, MD. The Role of Earthquake Hazard Maps in Loss Estimation: A Study of the Northridge Earthquake, Discussion of paper by R.B. 
Olshansky, Earthquake Spectra, 14(3); 1998. p. 557-563.

[63] Todorovska MI, Trifunac MD. A seismic hazard model for peak strains in soils during strong earthquake shaking. Earthq Eng Eng Vib 1996;16:1-12.

[64] Todorovska MI, Trifunac MD. Hazard mapping of normalized peak strain in soil during earthquakes - microzonation of a metropolitan area. Soil Dyn Earthq Eng 1996;15(5):321-9.

[65] Todorovska MI, Trifunac MD. Discussion of "The role of earthquake hazard maps in loss estimation: a study of the Northridge Earthquake," by R.B. Olshansky, Earthquake Spectra, 14(3); 1998. pp. 557-563.

[66] Todorovska MI, Gupta ID, Gupta VK, Lee VW, Trifunac MD. Selected topics in probabilistic seismic hazard analysis. Los Angeles, California: Dept. of Civil Eng. Univ. of Southern California; 1995. [Report No. CE 95-08].

[67] Todorovska MI, Lee VW, Trifunac MD. Shaking hazard compatible methodology for probabilistic assessment of permanent ground displacement across earthquake faults. Soil Dyn Earthq Eng 2007;27(6):586-97.

[68] Todorovska MI, Trifunac MD, Lee VW. Probabilistic Assessment of Permanent Ground Displacement Across Earthquake Faults. In: Proceedings of the Earthquake Engineering in the 21st Century to mark 40th anniversary of IZIIS - Skopje, August 28-Sptember 1, 2005, Skopje and Ohrid, Macedonia; 2005.

[69] Trifunac MD. Seismic Microzonation Mapping Via Uniform Risk Spectra. In: Proceedings of the 9th World Conference Earthquake Eng., VII, 75-80, Tokyo-Kyoto, Japan; 1988.

[70] Trifunac MD. Threshold magnitudes, which exceed the expected ground motion during the next 50 years in a metropolitan area. Geofizika 1989;6:1-12.

[71] Trifunac MD. How to model amplification of strong earthquake ground motions by local soil \& geologic site conditions. Earthq Eng Struct Dyn 1990;19(6):833-46.

[72] Trifunac MD. 75th anniversary of the response spectrum method - a historical review. Soil Dyn Earthq Eng 2008;28(9):676-85. [2008].

[73] Trifunac MD. The Nature of Site Response During Earthquakes, Proc. NATO ARW workshop in Borovec, 30 August - 3 September, 2008, Bulgaria, published in Coupled Site and Soil-Structure Interaction effects with Applications to Seismic Risk Mitigation (T. Schantz and R. Iankov editors), NATO Science for Piece and Security Series C: Environmental Security, 3-31, Springer Science + Business Media, B. V. 2009; 2008.
[74] Trifunac MD. Seismic Microzonation and Near-Field Effects, In: Proceedings of the 9th International Workshop on Seismic Microzoning and Risk Reduction (9IWSMRR), Cuernavaca, Morelos, Mexico, 21-24 February 2010; 2010.

[75] Trifunac MD. Earthquake response spectra for performance based design - a critical review. Soil Dyn Earthq Eng 2012;37(6):73-83.

[76] Trifunac MD. Site conditions and earthquake ground motion - a review. Soil Dyn Earthq Eng 2016;11(4):229-41.

[77] Trifunac MD, Brady AG. On the correlation of seismic intensity scales with the peaks of recording strong ground motion. Bull Seismol Soc Am 1975;90:88-100.

[78] Trifunac MD, Ivanović SS. Reoccurrence of site specific response in former Yugoslavia - part I: Montenegro. Soil Dyn Earthq Eng 2003;23(8):637-61.

[79] Trifunac MD, Ivanović SS. Reoccurrence of site specific response in former Yugoslavia - Part II: Friuli, Banja Luka and Kopaonik. Soil Dyn Earthq Eng 2003;23(8):663-81.

[80] Trifunac MD, Todorovska MI. Nonlinear soil response as a natural passive isolation mechanism - the 1994 Northridge, California Earthquake. Soil Dyn Earthq Eng 1998;17(1):41-51.

[81] Udwadia FE, Trifunac MD. Characterization of response spectra through the statistics of oscillator response. Bull Seism Soc Am 1974;64(1):205-19.

[82] UNESCO. The Skopje earthquake 1963, Report of the UNESCO Technical Assistance Mission, Printed in Netherlands, Amsterdam, NS.66/D.47/AF; 1968.

[83] Wenzel F, Lorenz FP, Sperner B, Oncescu MC. Seismotectonics of the Romanian Vrancea Area. In: Vrancea Earthquakes :Tectonics, Hazard and Risk Mitigation, (edited by Wenzel et al.); 1999. pp. 15-25.

[84] Weichert DH. Estimation of the earthquake recurrence parameters for unequal observation periods for different magnitudes. Bull Seism Soc Am 1980;70:1337-46.

[85] Wells DL, Coppersmith JK. New empirical relations among magnitude, rupture width, rupture area, and surface displacement. Bull Seism Soc Am 1994;84:974-1002.

[86] Zatopek A. The Skopje earthquake of July 26, 1963, and seismicity of Macedonia (Preliminary report for UNESCO-Paris, Belgrade). 1964; 1964.

[87] Zatopek A. The Skopje earthquake of July 26, 1963, and seismicity of Macedonia (The Skopje Earthquake 1963). 1968; 1968. p. 89-129. (Unesco 1968, Netherlands, NS.66/D.47/AF). 